$$
\text { "العلوم التربوية بحوث }
$$

\title{
فعالية برنامج علاجي لصعوبات تعلم القراعة لاي تلاميذ المرحلة الابتدائية ذوي النمط الأيمن في معالجة المعلومات
}

حنان سامي تحمل حامد*

$$
\text { إثراف }
$$



أ.د/ أسماء عبد المنعم إبراهيم **















وتمنلت أدوات البحث في مقياس التقدير التشخيصـي لصعوبات تعلم القر اءة إعداد فتحي مصطفي









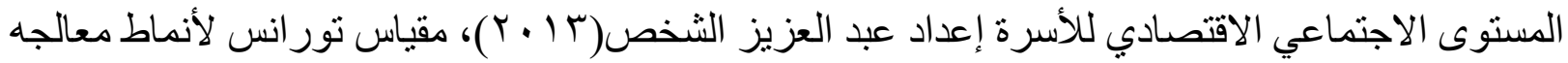





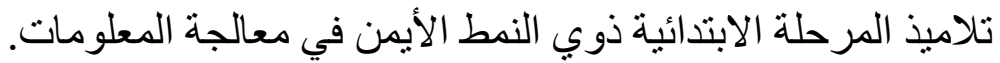












\section{مقدمة البحث:}

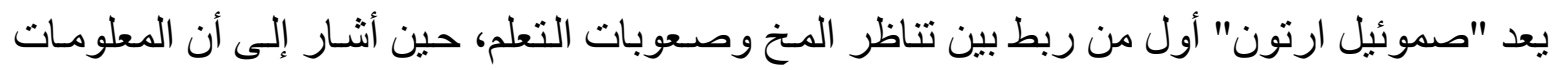

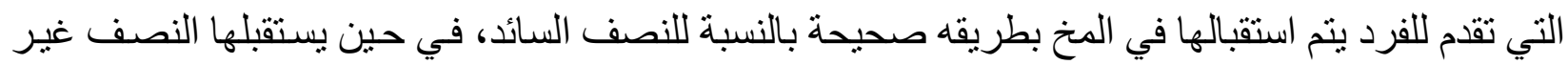

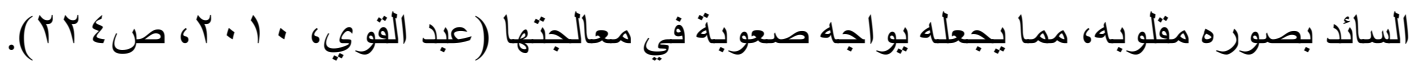

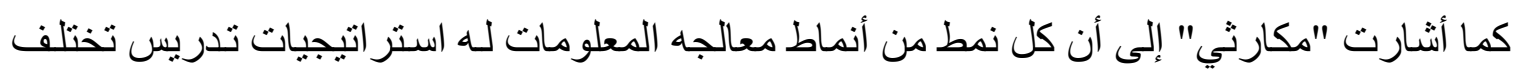

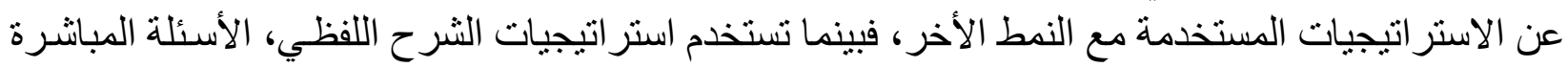


الأيمن في معالجة المعلومات، (Mc Carthy, R\& Warrington, E, 1990, p164).







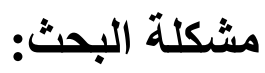

انبتقت مشكله البحث الر اهنة عن طريق ملاحظة الباحثة أثنـاء عملها أن الصعوبات التي يو اجها






نفس الدرجة من الصعوبة.




التقليدية في التدريس و التي غالبا تخاطب النصف الأيسر (Allington-Smith,2006,p134)

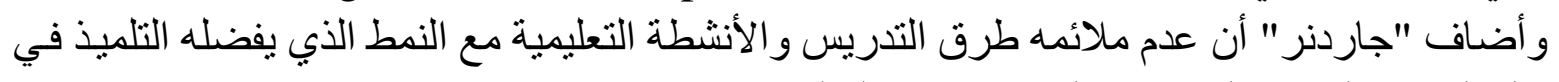

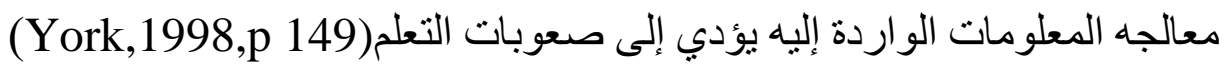

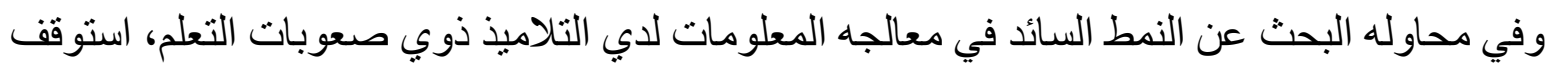

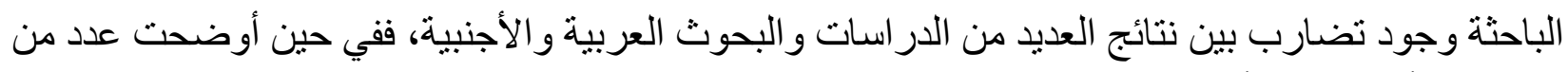

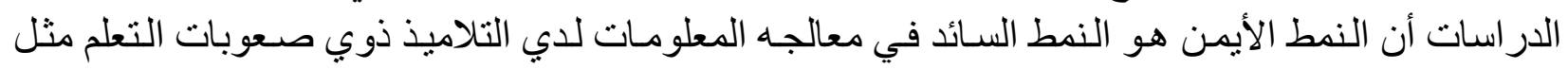

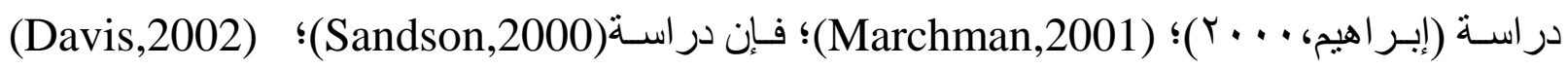

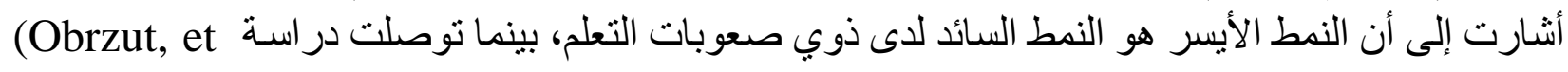

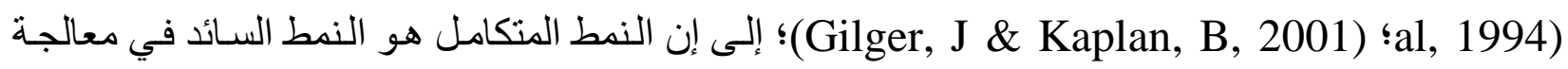
المعلومات لدى التلاميذ ذوي صعوبات التعلم. 



مجلة بحوث

"العلوم التربوية"

ومن هنا برزت ضرورة النظر إلى التلاميذ ذوي صعوبات تعلم القراءة في ضوء الفروق بينهم في نمط

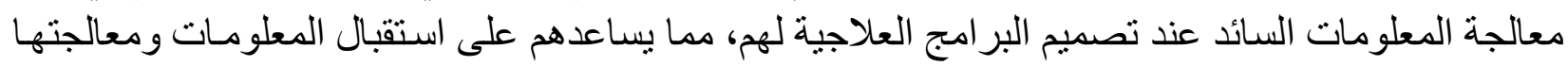

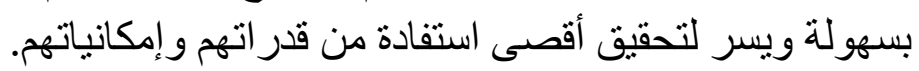

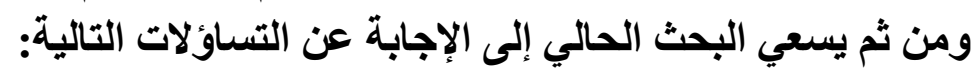

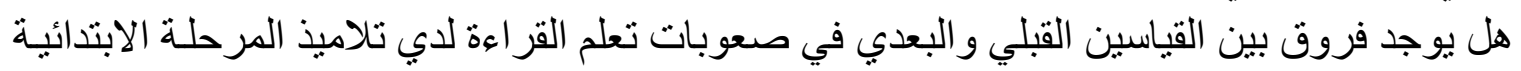

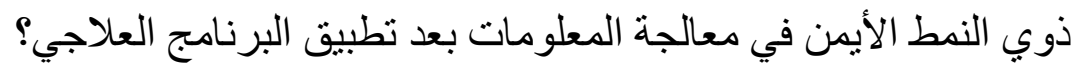

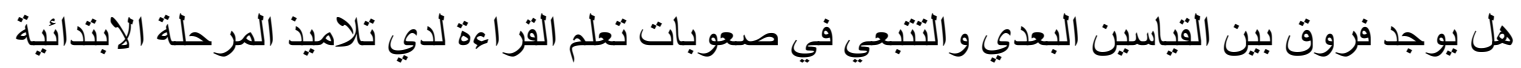
ذوي النمط الأيمن في معالجة المعلومات؟ أهداف البحث:

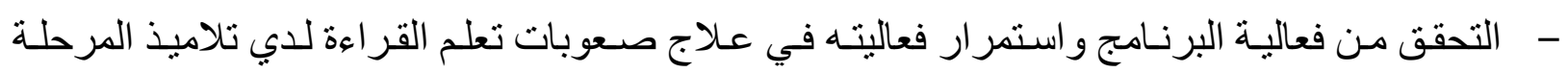
الابتدائية ذوي النمط الأيمن في معالجة المعلومات

أهمية البحث

\section{الجانب الأول: الأهمية النظرية: وتتمثل في:}














التعريفات الإجرائية لمصطلحات الدراست فئات

- البرنامج العلاجي :Treatment Program هو برنامج ينم إعداده في ضوء وأسس علمينة، وفق نتائج




المهار ات التي يجد صعوبة في تعلمهات التهات

- صعوبات تعلم القراعة:Reading Disabilities هي انخفاض دال في قدرة التلميذ على القر اءة و التي

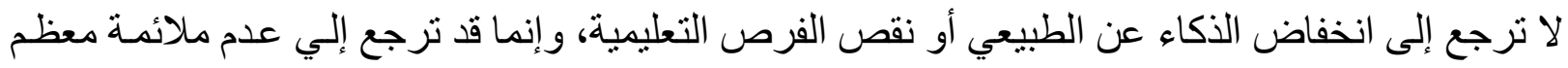

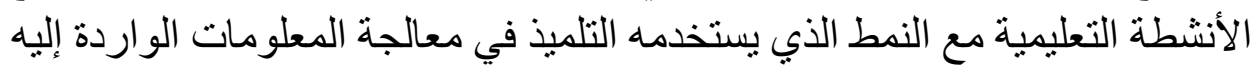

Information The right hemisphere to process النمط الأيمن في معالجة المعلومات 




\section{مجلة بحوث \\ "العلوم التربوية"}

هو سيادة النصف الأيمن من المخ مما يجعل الفرد يميل إلى استخدامه في استقبال ومعالجة المعلومات

الإطار النظري هو سبادة النظ

أولاً: البرنامج العلاجي Treatment program

تضم البر امج العلاجية عدد من العناصر تتمثل في الأهداف، المـادة التعليميـة، التدريبات العلاجية الوسيائل

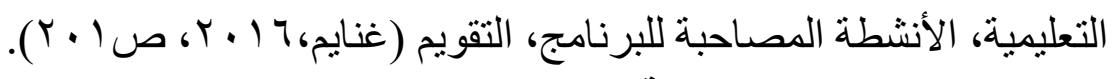
خطوات تصميم البرامج العلاجية:

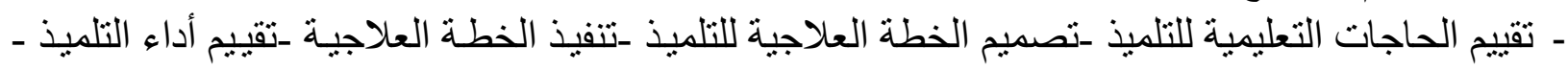





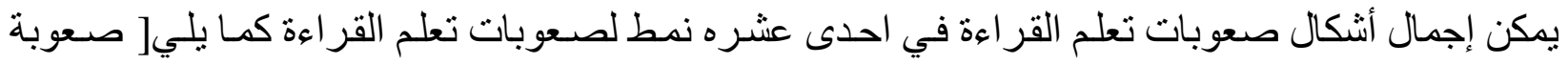

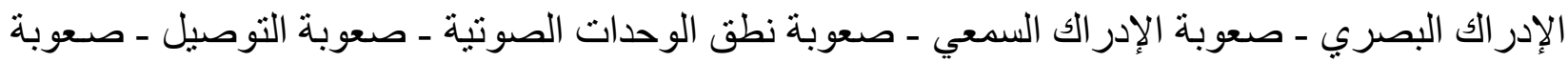

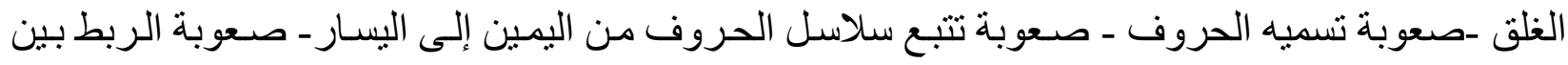

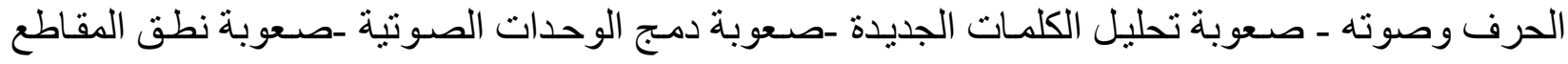



محكات التشخيص



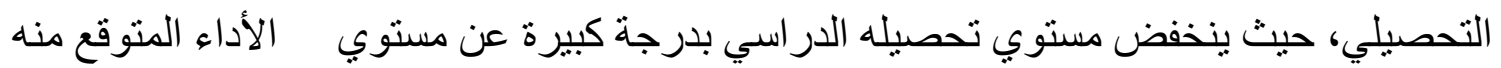







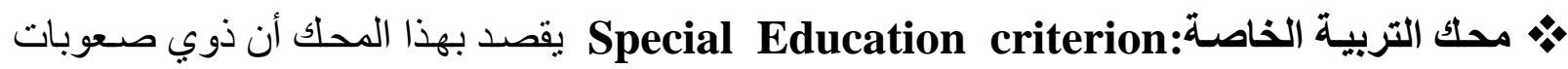



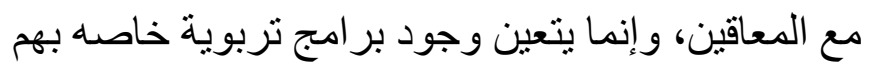

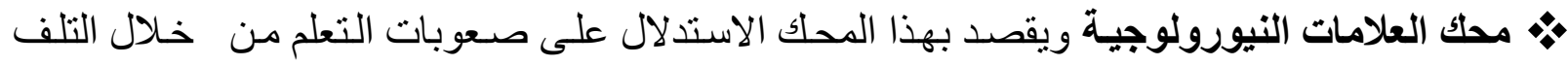

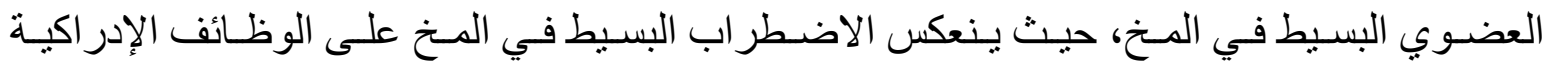

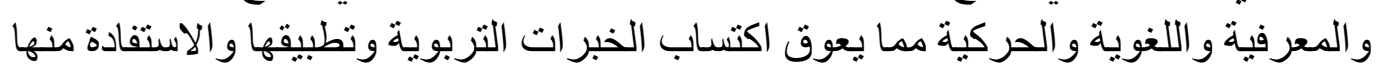



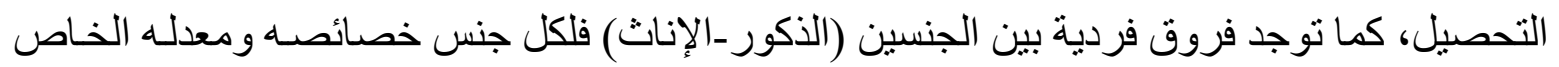

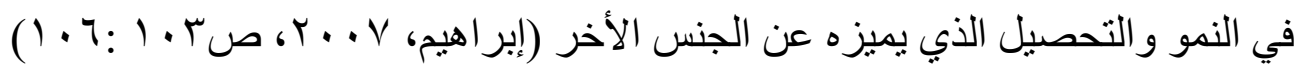
علاج صعوبات تعلم القراءة يمكن تصنيف الاتجاهات الحديثة في علاج صعوبات تعلم القراءة إلى محورين أساسيين هما: 


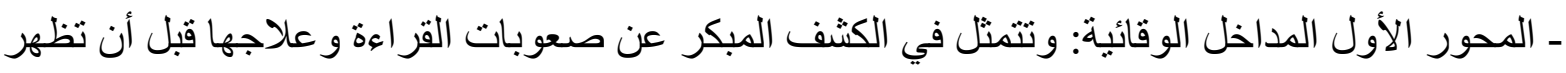

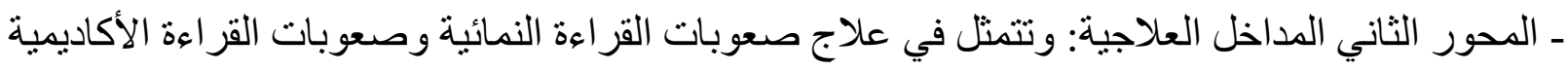

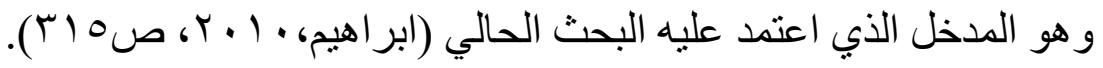
ثالثاً: النمط الأيمن في معالجة المعلومات المنات

\section{The right hemisphere to process information}

يعتبر الطبيب الفرنسي"مارك داكس"Mark Dax أول من بحث في مدي مسئوليه نصفي المخ عن أنشطة

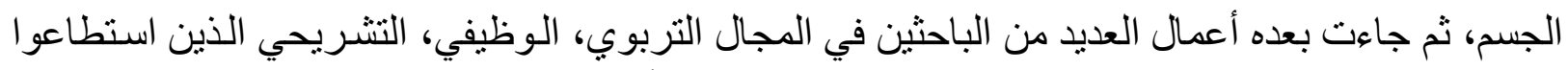

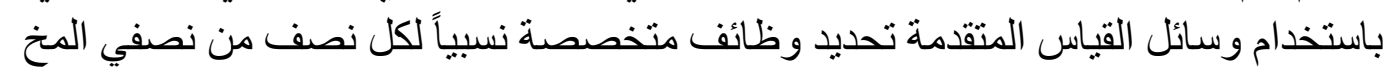

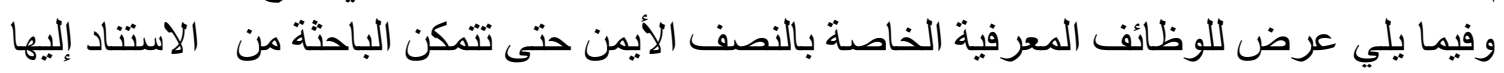

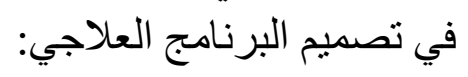





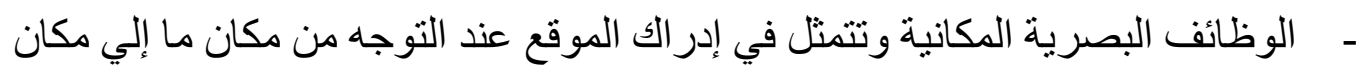



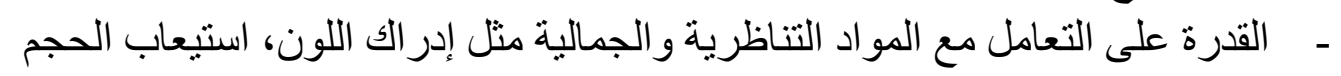







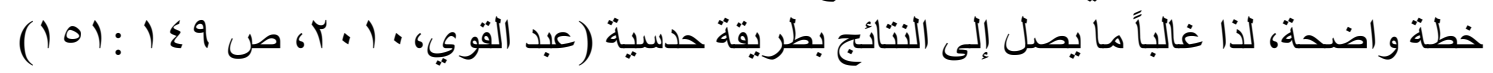

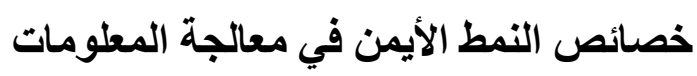

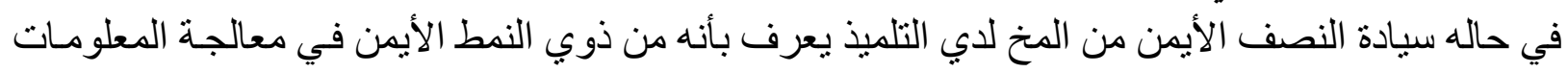

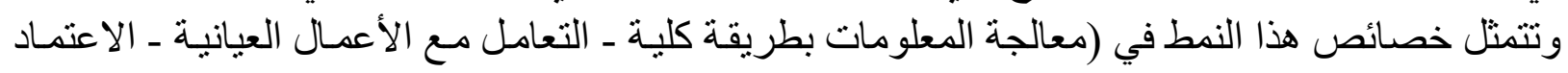

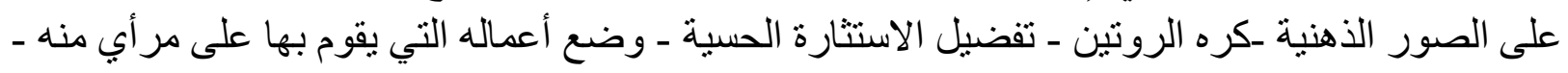



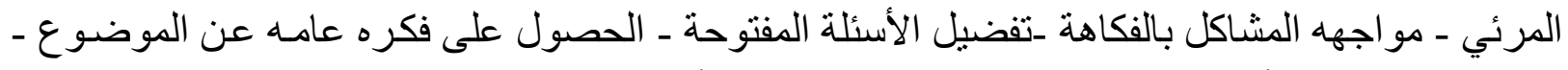

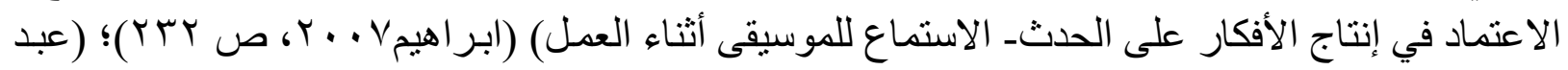

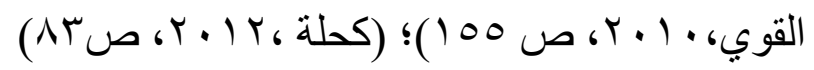
استراتيجيات تدريس النمط الأيمن في معالجة المعلومات المات

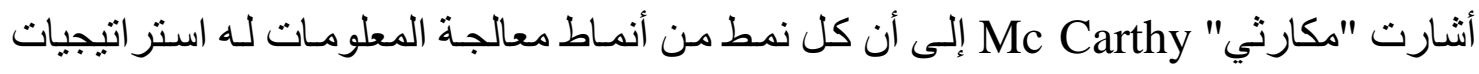

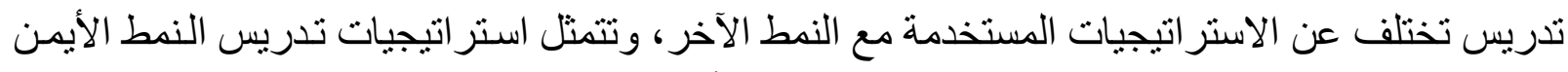

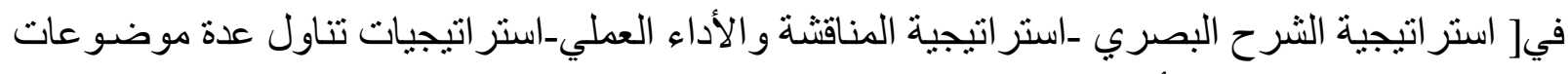

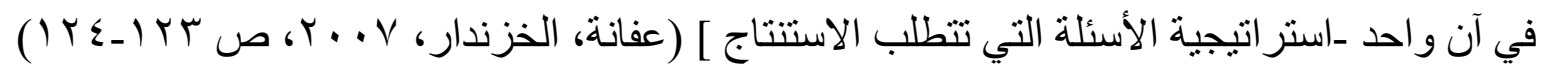


العدد الثانى - الجزء الثانى (ا「•Г)

مجلة بحوث

"العلوم التربوية"

دراسات سابقة

المحور الأول: دراسات تناولت برامج لعلاج صعوبات تعلم القراعة

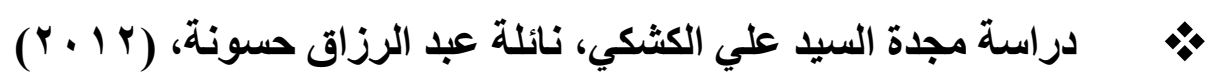

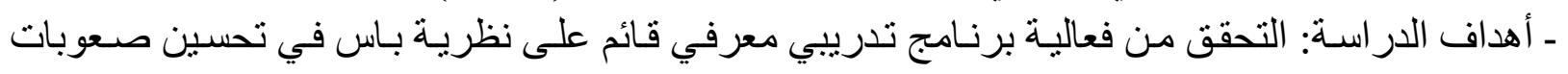
القر اءة لاي تلميذات المرحلة الابتدائية

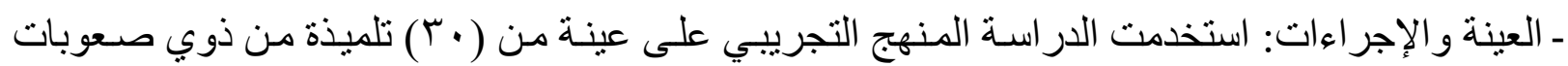

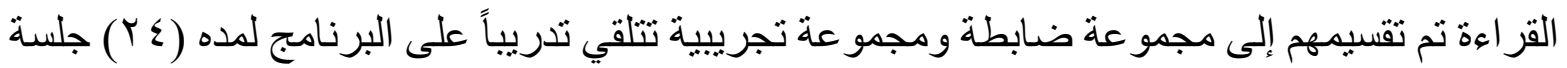

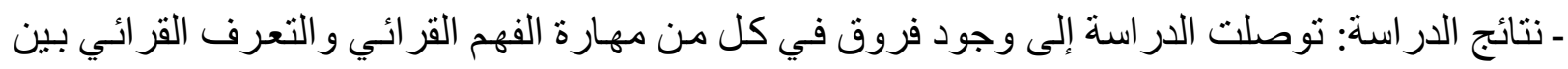

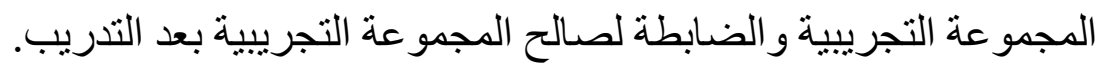

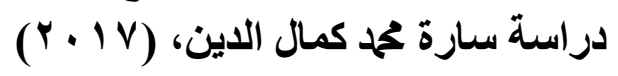

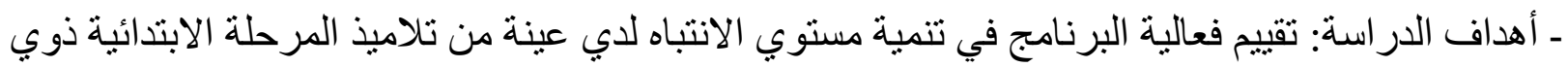

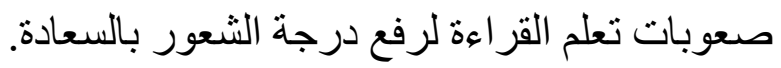

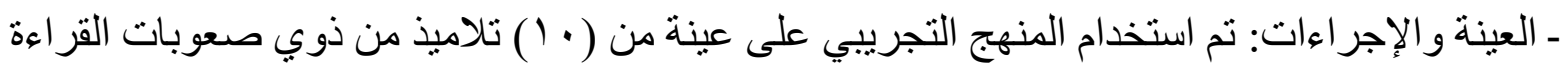

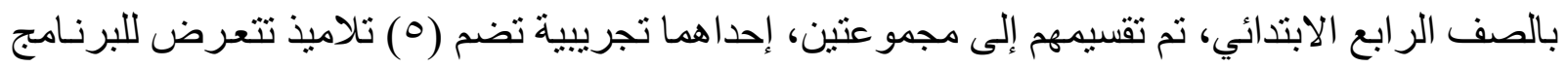

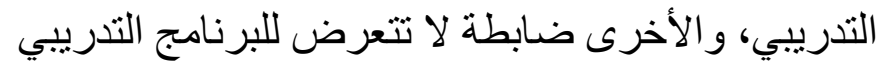

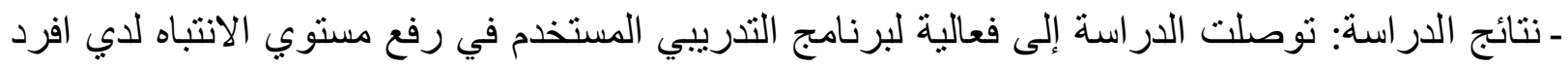

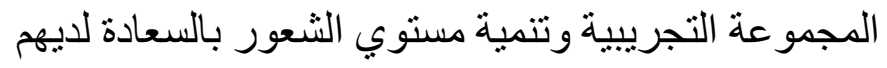
المحور الثاني: دراسات تناولت الكثف عن وظائف النصف الأيمن من المخخ

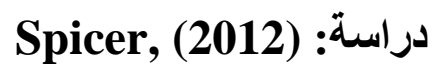

ـ ـ أهداف الدراسة: التعرف على دور النصف الأيمن من الدخ في الوظائف الدعرفية لدي الاطفال

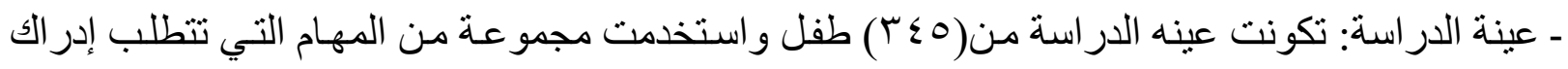

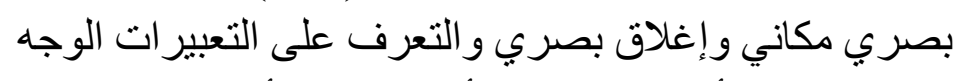

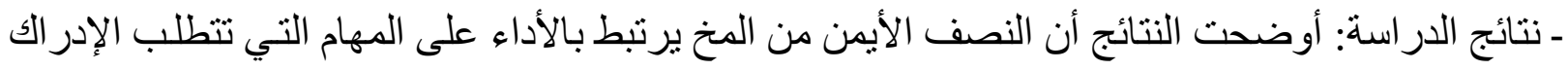

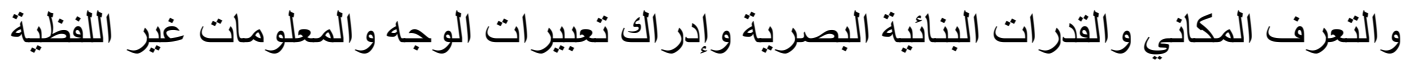

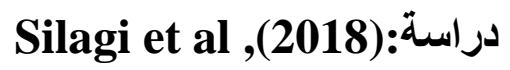

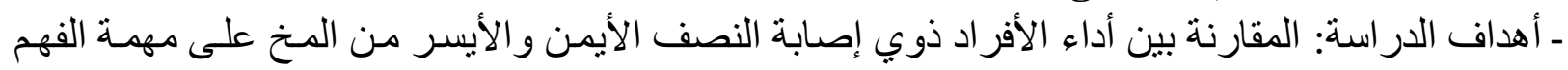

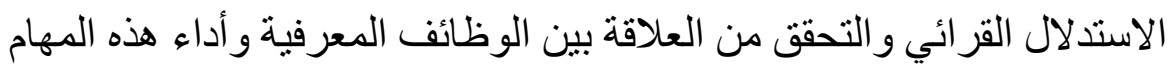

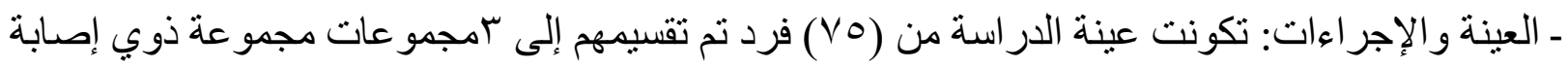
النصف الأيمن، النصف الأيسر من المخ ومجمو عة ضابطة 


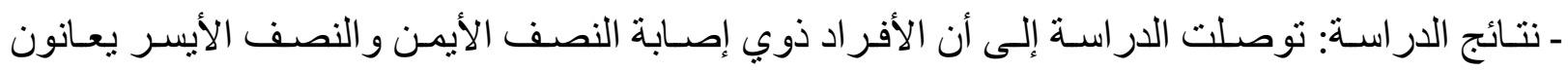

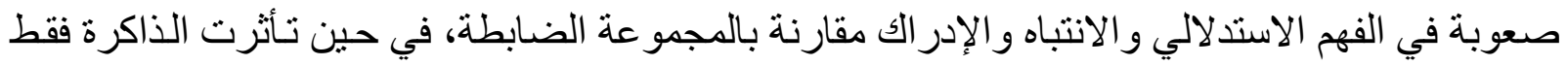

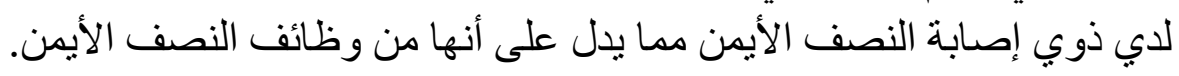

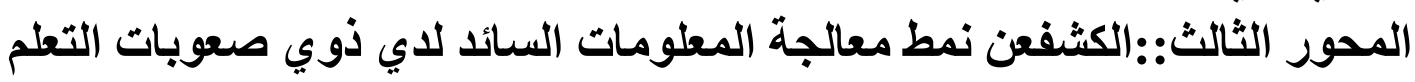

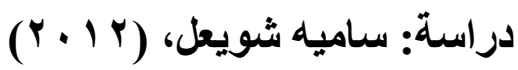

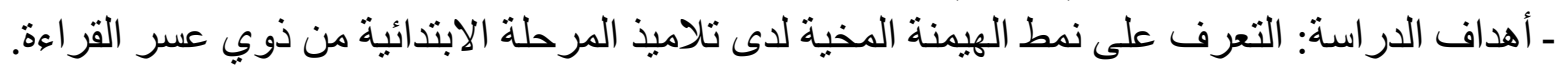

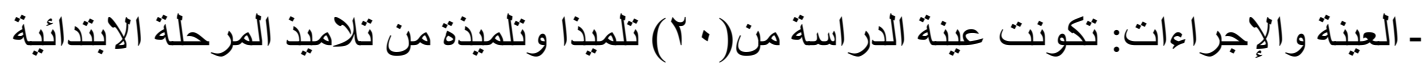

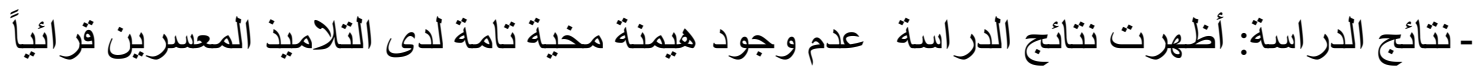

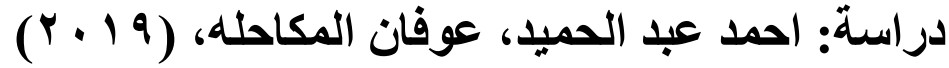

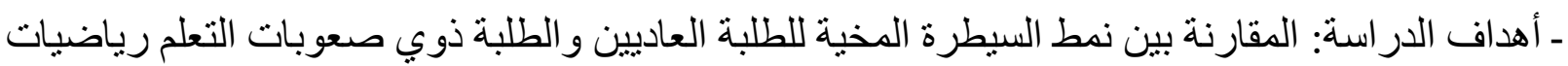

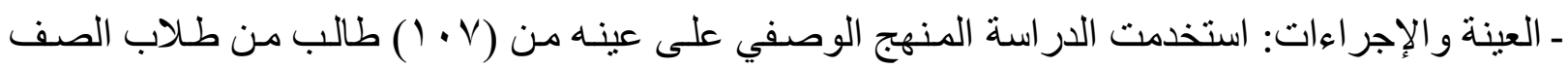

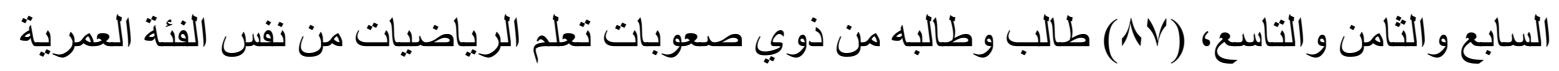

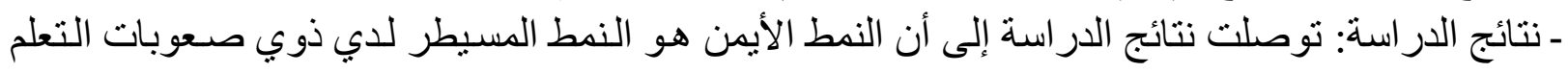

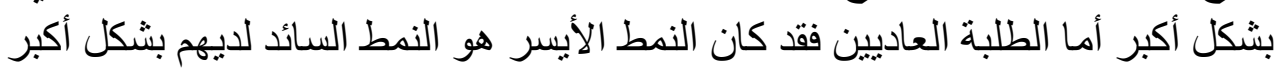

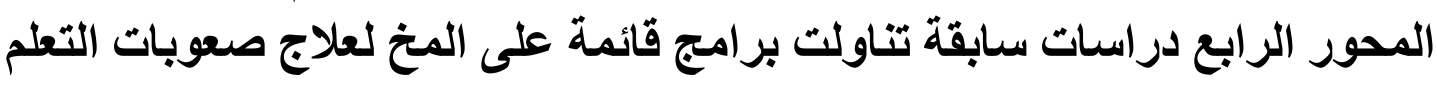

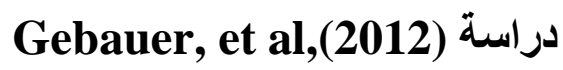

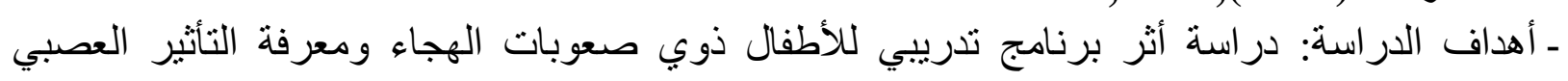

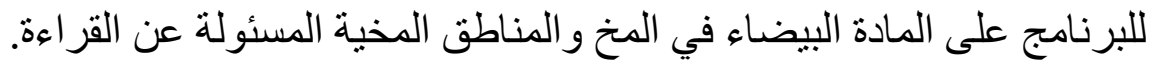

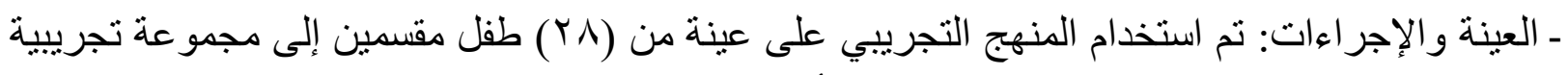

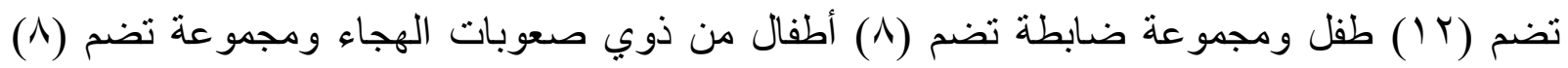

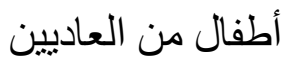

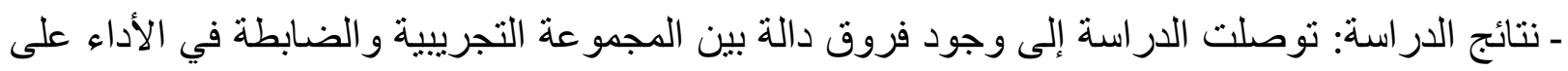

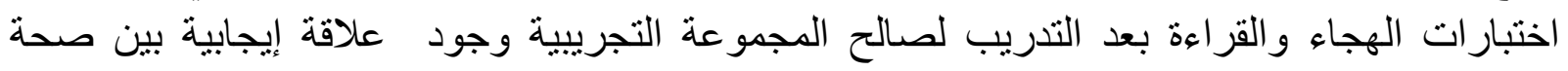

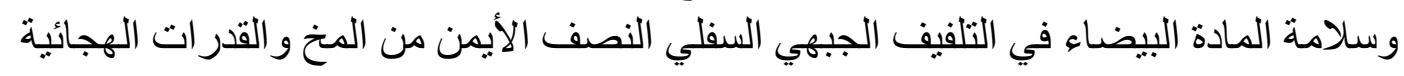

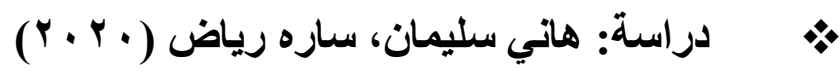

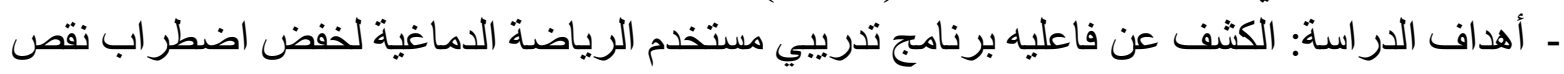

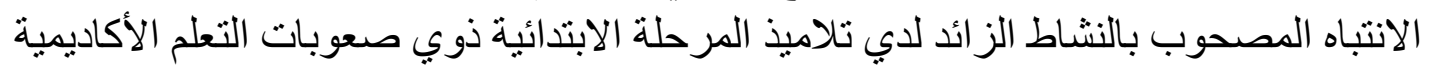

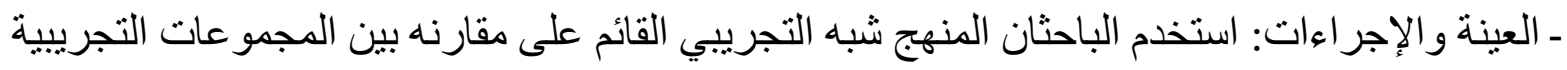

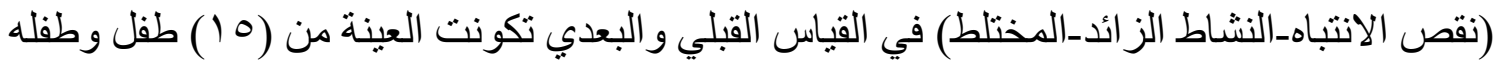

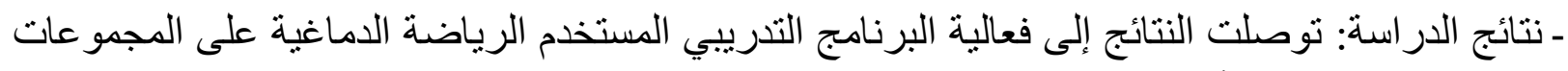

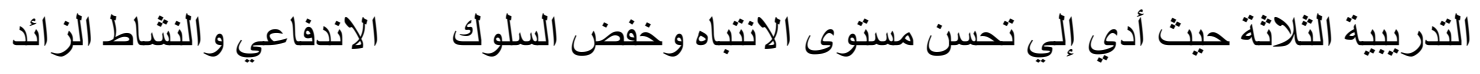
تعقيب على الار اسات السابقة: 
استفادة الباحثة من الدر اسات السابقة ذات الصلة بموضو ع البحث الر اهن في:

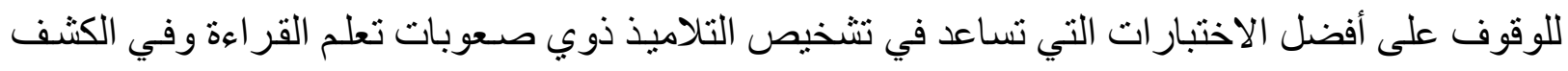

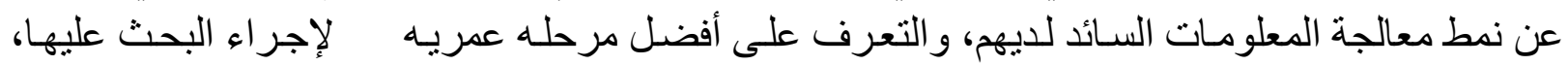

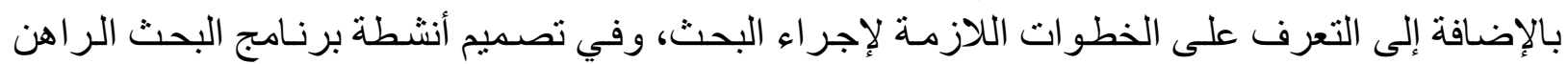

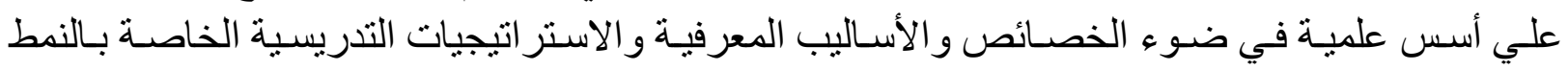
الأيمن للوقوف على أفضل الطرق التي تقدم بها المعلومات بشكل يمكنه من استقبالها ومعالجتها.

فروض البحث

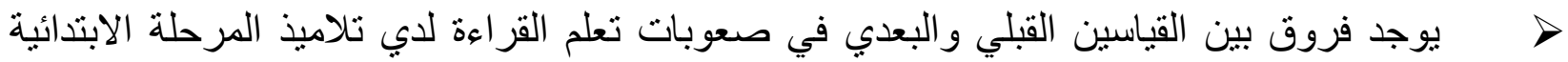

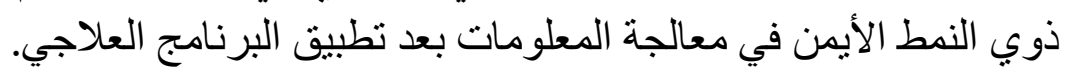

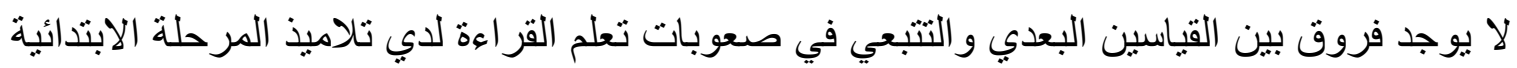

\section{منهج وإجراعات البحث}

ذوي النمط الأيمن في معالجة المعلومات.

ـ منهج البحث: اعتمد البحث الحالي على المنهج التجريبي (تصميم المجموعة الواحدة) للتحقق من فعالية

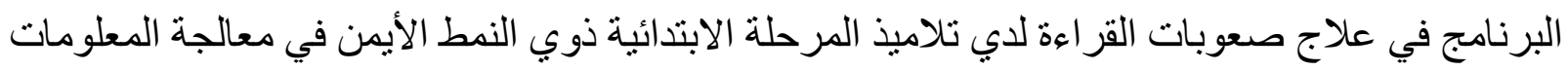

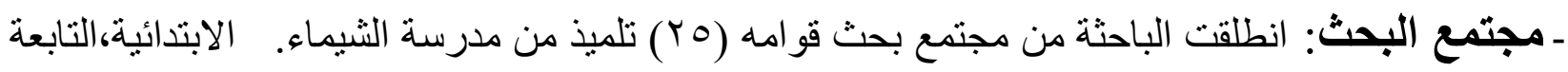

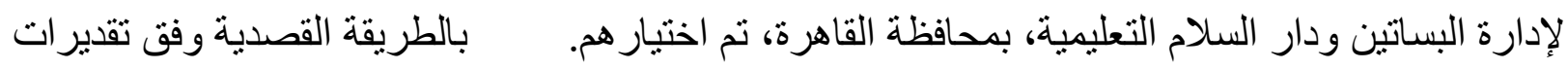
معلمي اللغة العربية على مقياس التقدير التشخيصي لصعوبات التهائ تعلم القراءة نظراً لأنهم أكثر احتكاكاً

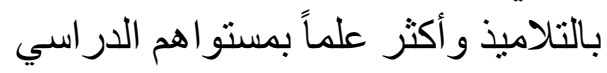

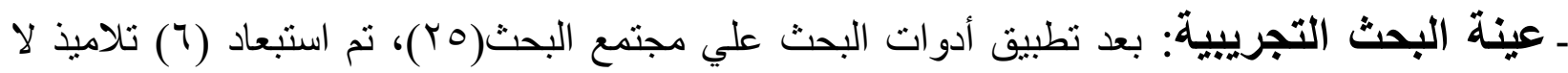

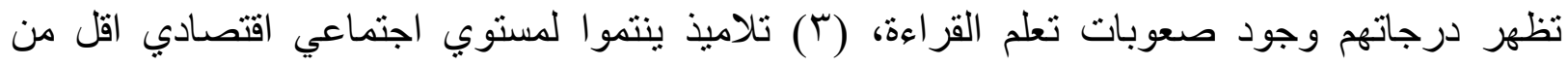

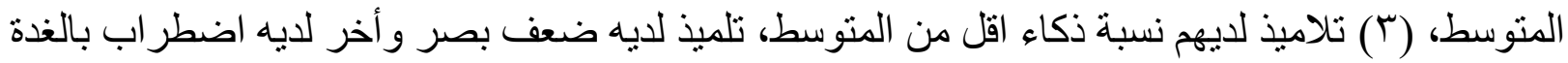

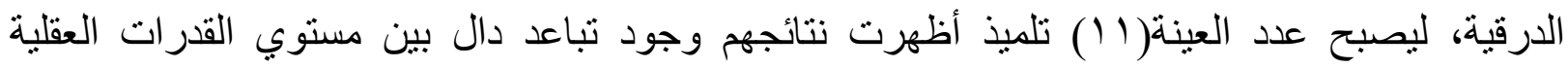

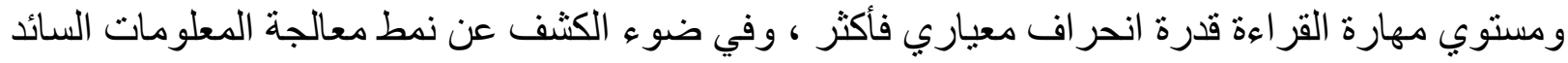

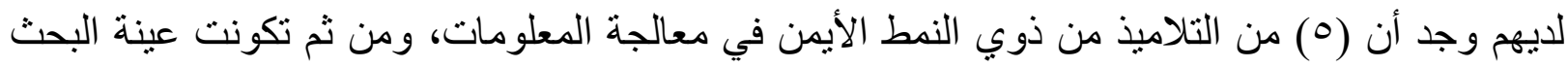

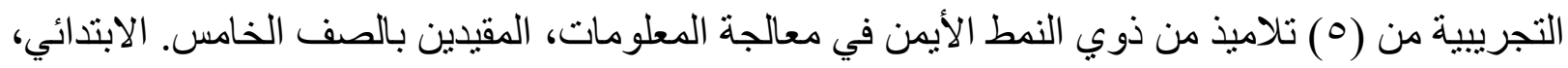

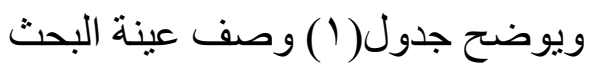

جدول( (1) وصف عينة البحث التجريبيى

\begin{tabular}{|c|c|c|c|}
\hline صعوبات شديدة & صعوبات متوبطة & صعوبات خفيفة & طبيعي \\
\hline آ فأكثر & $7 .-\{1$ & $\varepsilon \cdot-r)$ & صفز - بr \\
\hline
\end{tabular}




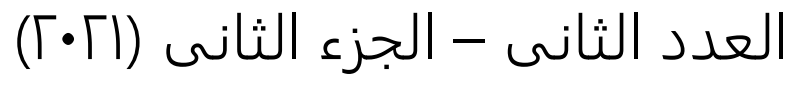
مجلة بحوث
"العلوم التربوية"

أدوات البحث

أولا: أدوات التشخيص

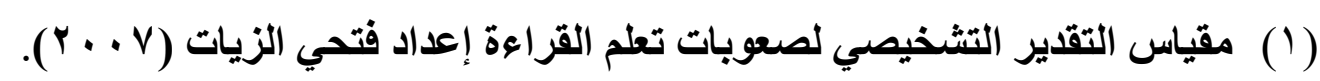

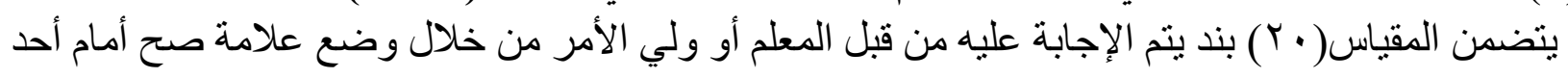

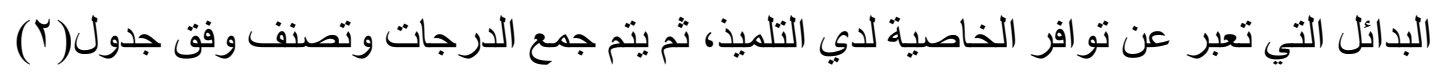

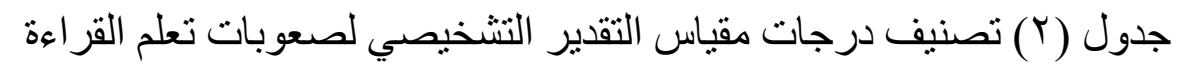

\begin{tabular}{|c|c|}
\hline عينة الجحث التجريبة & الصفة \\
\hline 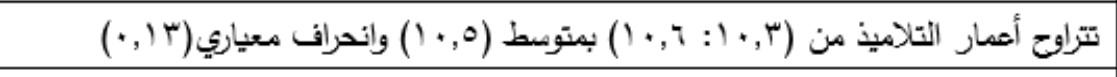 & العسر \\
\hline ذكور & النوع \\
\hline 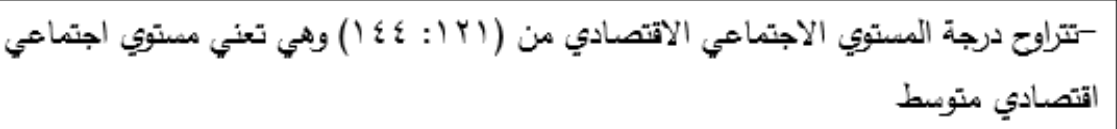 & المستوي الاجتماهي: \\
\hline 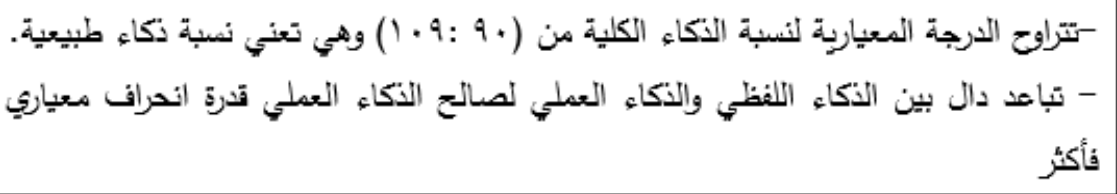 & مستوي الذكاء \\
\hline مستوي القزاءء اتل من (• (7) \% وهي تعني وجود صعوبات تعلم قراءة & مستوي القزاءة \\
\hline
\end{tabular}

الذا

كوماترية للمقياس

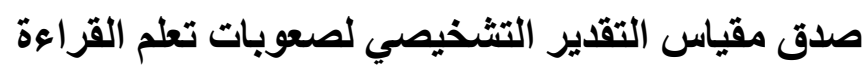

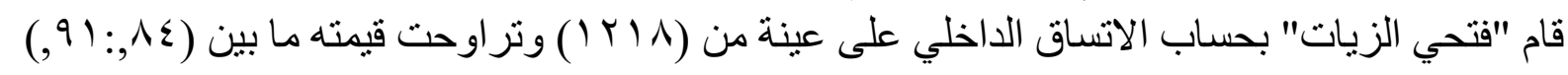

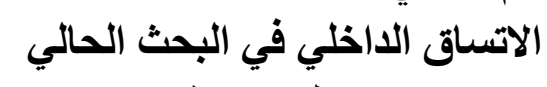

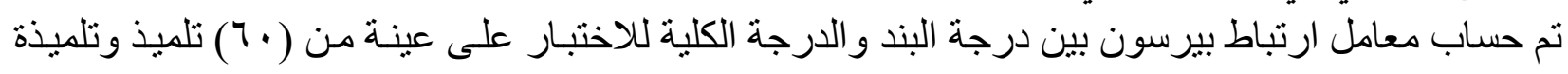

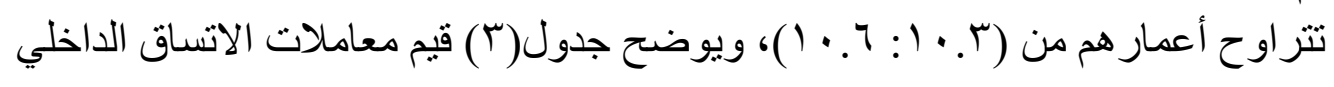




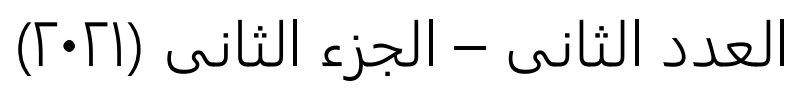
مجلة بحوث

"العلوم التربوية"

جدول(r) حساب الاتساق الداخلي لمقياس التقدير التشخيصي لصعوبات تعلم القراءة

\begin{tabular}{|c|c|c|c|c|c|c|c|}
\hline معامل الارتباط & النيند & معامل الازتباط & النبد & معامل الارتباط & البند & معامل الازتباط & البند \\
\hline$\cdot, \lambda V$ & 17 & $*, 9$. & 11 & $\cdot, \wedge \varepsilon$ & 7 & ", & । \\
\hline$*, \wedge \wedge$ & IV & ז, & Ir & $\cdot, \vee 9$ & 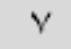 &,$+ V_{0}$ & $r$ \\
\hline$*, 9$. & $1 \wedge$ & $\cdot, 91$ & rו & $\cdot, 9$. & $\wedge$ & $\cdot, \wedge 9$ & r \\
\hline ד & 19 & $*, 9 *$ & $1 \varepsilon$ & ד ד & 9 & $+, 9)$ & $\varepsilon$ \\
\hline,+ 199 & $r$. & $*, 人 7$ & 10 & $\cdot, \wedge 9$ & 1. & $*, 9$. & 0 \\
\hline
\end{tabular}

وقد تراوحت قيم معاملات الاتساق ما بين (19. • : ب9. • ) وهي معاملات اتساق مرتفعة مما يشير إلى أن

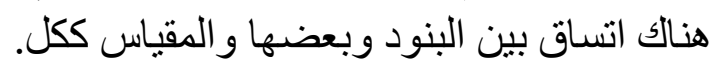

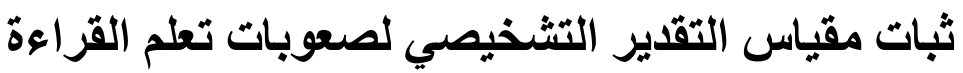

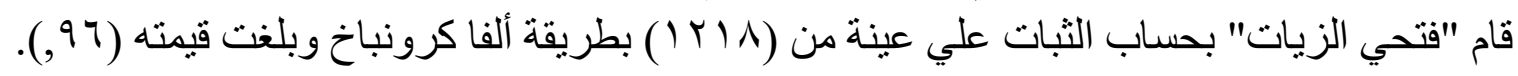

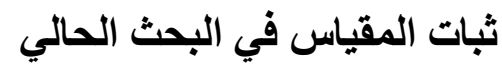

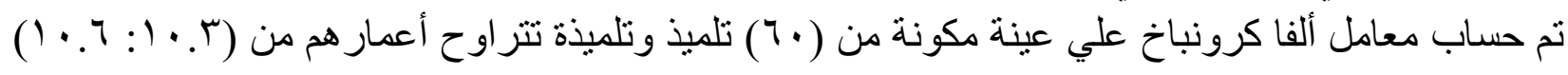

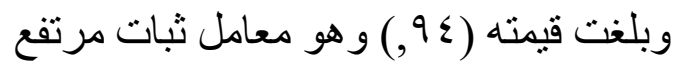

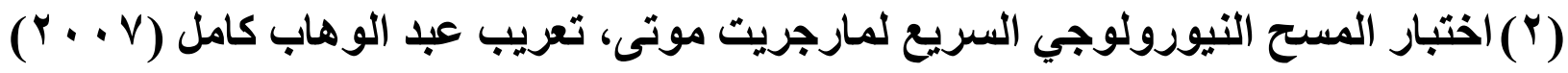

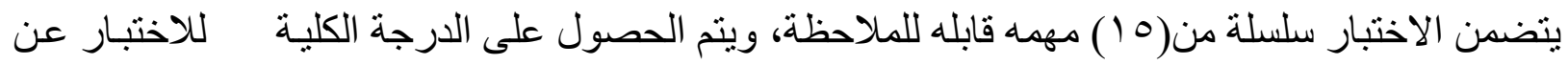

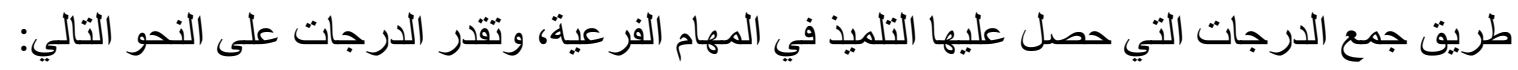

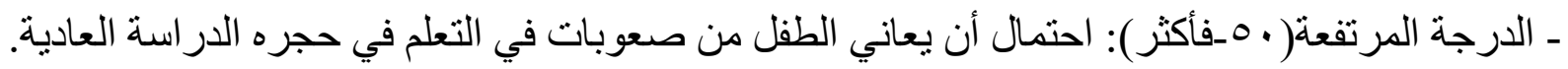

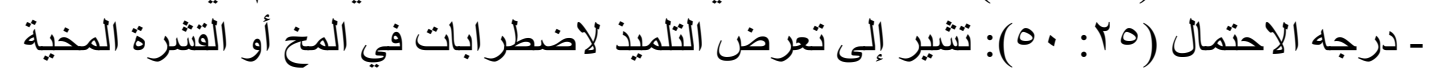

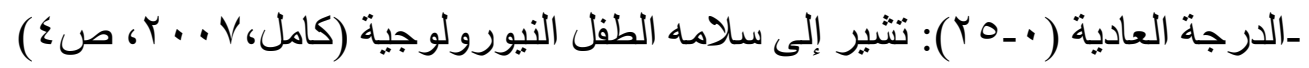
الخصائص السيكومتريه للاختبار

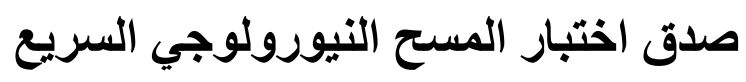

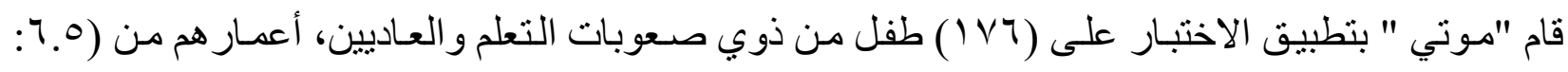

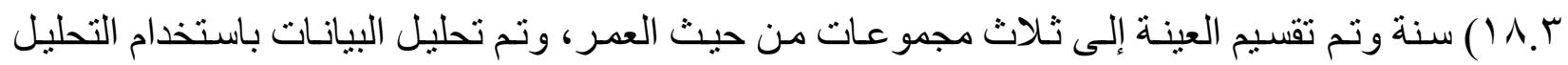

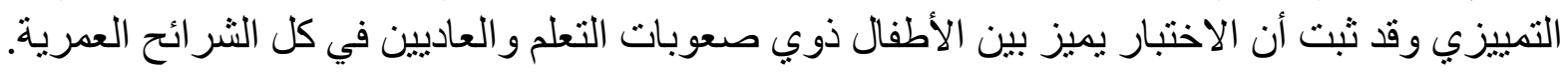
صدق الاختبار في البيئة العربية الإنية

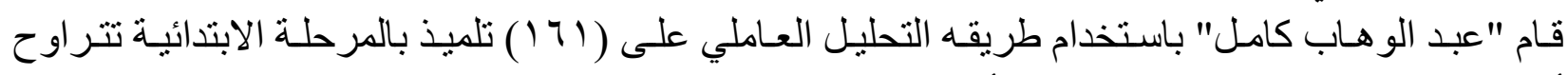

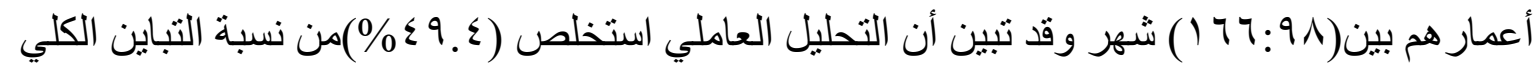
الاتساق الاخلي في البحث الحالي نم حساب معامل ارتباط بيرسون بين درجة المهية والداني الدرجة الكلية للاختبار، ويوضح جدول(ع) قيم المعاملات 


$$
\text { "العلوم التربوية" } \begin{array}{r}
\text { "مجلة بحوث } \\
\hline \hline
\end{array}
$$

\begin{tabular}{|c|c|c|c|c|c|}
\hline معامل الارتباط & المهمة & معامل الارتباط & المهمة & معامل الارتباط & المهمة \\
\hline$\cdot, \wedge 7$ & المهمة (1') & $\cdot, 9$. & المهمة(7) & $*, V_{7}$ & المهمة (1) \\
\hline$\cdot, V \varepsilon$ & المهمة(Y I) & $\cdot, \wedge 9$ & المهمة(V) & , vo & المهمة(r) \\
\hline$\cdot, \mathrm{V}$ & المهمة (r ا) & $\cdot, V_{7}$ & المهمة(^) & س & المهمة (r) \\
\hline •, یז & المهمة (ع ا) & $\cdot, \wedge \wedge$ & المهمة (9) &,+ 91 & المهمة (ع) \\
\hline V V & المهمة(10) & ש & المهمة(· ( ) & $\cdot, 19$ & المهمة(ه) \\
\hline
\end{tabular}

جدول(§) حساب الاتساق الداخلي لاختبار المسح النيورولوجي السريع

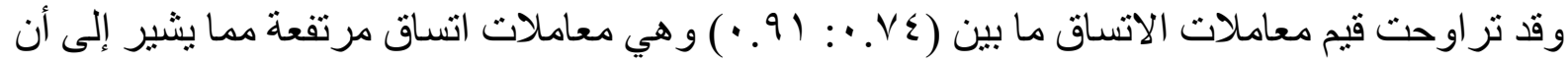

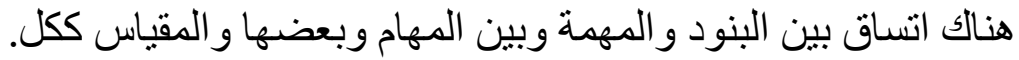

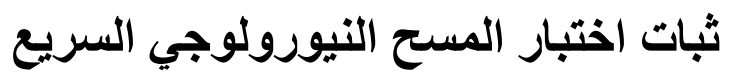

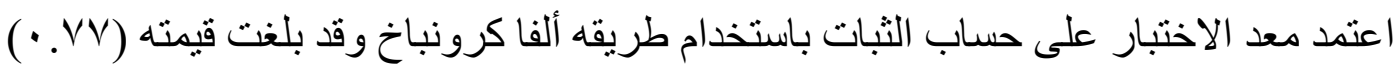
ثبات الاختبار في البيئة العربية

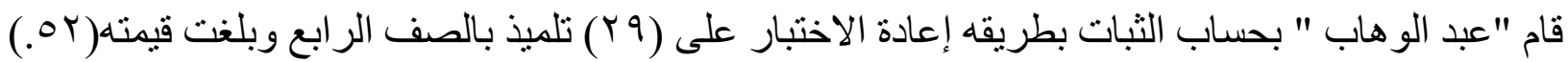

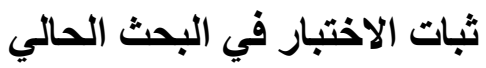

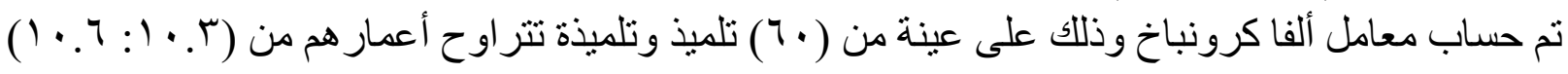

\begin{tabular}{|c|c|c|c|c|c|c|c|c|}
\hline الفاكرونباخ معامل & الكئود & المهمة & الفاكرونباخ & الكئود & المهيمة & الفاكرونباخ معامل & الكئود & المهمة \\
\hline r, & ᄉ & 11 & $\cdot, \wedge$. & $v$ & $T$ & $\cdot$, , & $\varepsilon$ & , \\
\hline$\cdot, \wedge$. & $\varepsilon$ & IT & $\cdot$, AV & $v$ & v & $\therefore$, vo & 11 & $r$ \\
\hline$\cdot, V r$ & $\varepsilon$ & ז & $\cdot$, ২A & 0 & 슨 & $\cdot, 19$ & 9 & $r$ \\
\hline 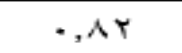 & $r$ & $1 \varepsilon$ & $\cdot \sqrt{9}$ & 0 & 9 & $\cdot, Y Y$ & $\varepsilon$ & $\varepsilon$ \\
\hline$\cdot$, , & 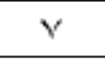 & 10 & $\cdot, \wedge)$ & $\mathrm{v}$ & 1. & דוג, & 9 & 。 \\
\hline$\cdot, 9$. & $9 \varepsilon$ & الدرجة الكلية & & & & & & \\
\hline
\end{tabular}
جدول(0) حساب ثبات اختبار المسح النيورولوجي السريع

تراوحت قيم معامل ألفا كرونباخ ما بين (VY.V. •: •9. • ) وهي معاملات ثبات مرتفعة

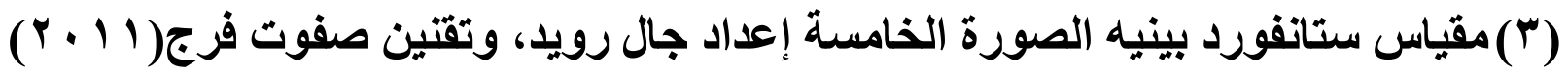




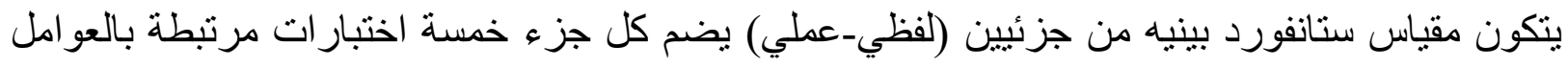

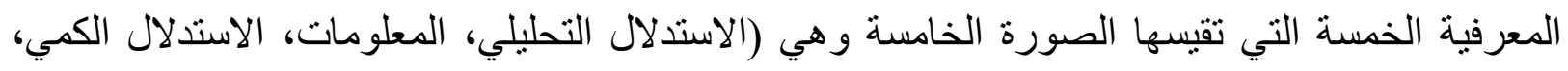

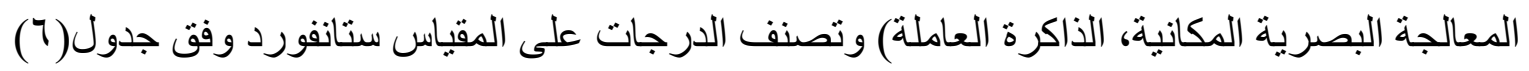
جدول ( (6تصنيف الدرجات على مقياس ستانفورد بينيه

\begin{tabular}{|c|c|c|c|}
\hline | الفئة & |الدرجة & | الفئة & الدرجة \\
\hline ادني من المتوصط & $(\wedge ৭-\wedge *)$ & موهوب للغاية & $(17,-1 \leq 0)$ \\
\hline ملى حدود التخلفـ & $(\vee ৭-\vee *)$ & موهوب & $\left(1 \leq \varepsilon-1 r_{*}\right)$ \\
\hline تخلفـ بنسط & $(79-\infty)$ & متفوق & $\left.(\mid)^{\prime}, r_{*}\right)$ \\
\hline تخلف متوسط & $(0 \varepsilon-\varepsilon \cdot)$ & منوسط مرتقع & $(1,9-1,+)$ \\
\hline |تخلف شديد & (rq-ro) & متوسط & $(1.9-9+)$ \\
\hline
\end{tabular}

صائص السيكومتريه للمقياس

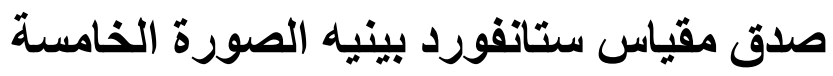

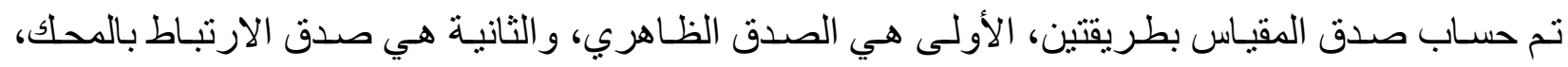

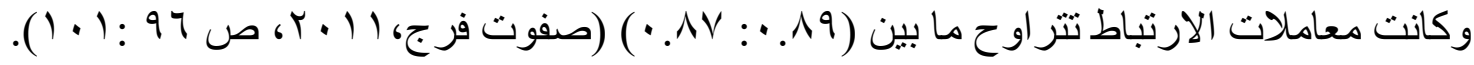

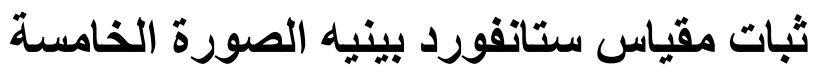

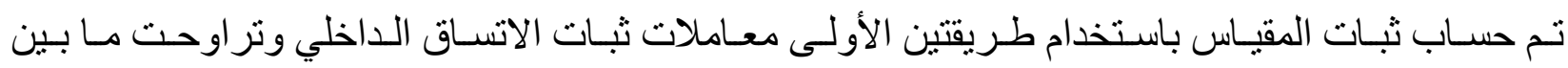

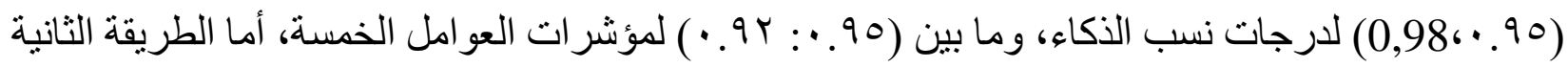

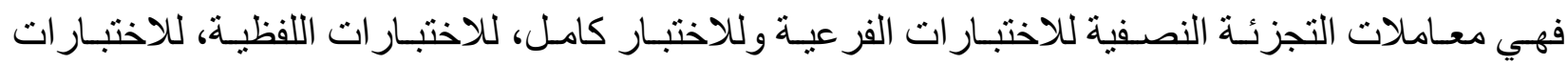

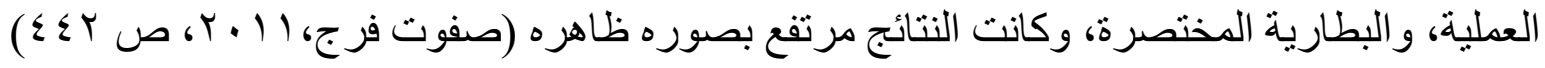

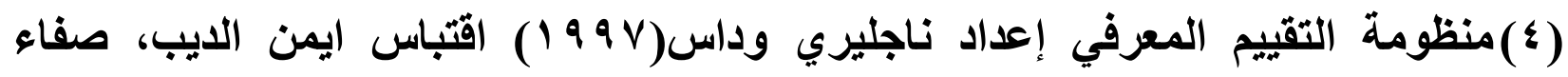

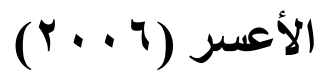

تتمثل أبعاد منظومة التقييم المعرفي في أربعة عمليات معرفية أساسية هي (التخطيط ـ الانتباهـ

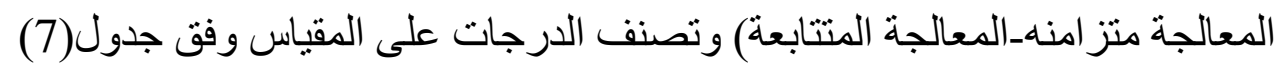

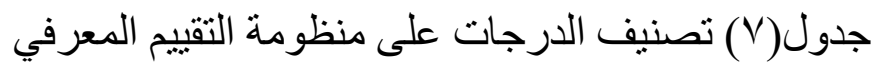

\begin{tabular}{|c|c|c|c|}
\hline التصنيفـ & الثرجة المعياربة & التصنيفـ & الدرجة المعيارية \\
\hline دون المتوسط & ᄉя-ᄉ. & ممتاز جدا & . س ا - أكثئ \\
\hline منخفض ع المتوسط & $\vee q-\gamma$. & ممتاز & Ira- Ir. \\
\hline منخفض جدا من المتوسط & اقل من 97 & متوسط مرتفع & $119-11$. \\
\hline & & متويط & $1+9-9$. \\
\hline
\end{tabular}




\section{الخصائص السيكوماترية للمنظومة صدق منظومة التقييم المعرفي}

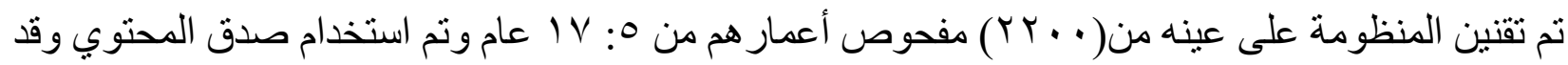
أثنارت النتائج أن هذه الاختبار ات الفر عية تعكس بدرجة كبيرة العيلة العمليات المعرفية الني أعدت لقياسها

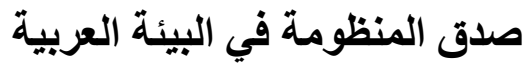

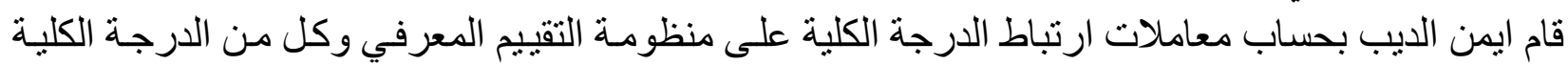

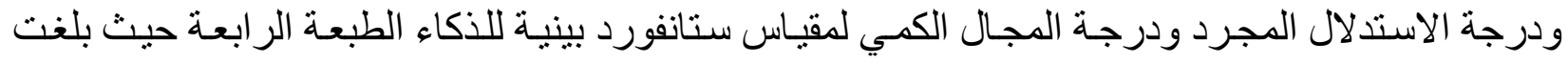

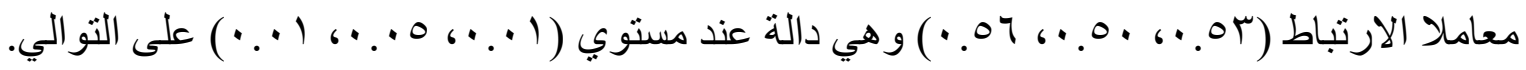

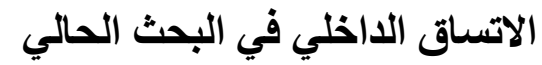

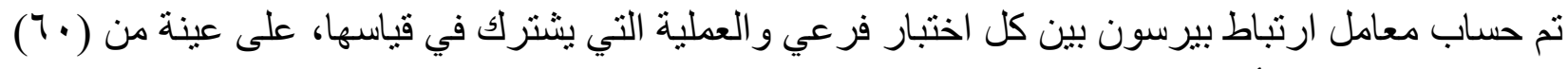

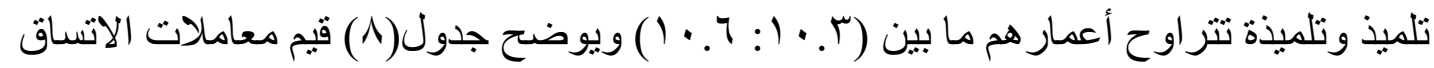
جدول(^) حساب الاتساق الداخلي لمقياس منظومة التقييم المعرفي

\begin{tabular}{|c|c|c|c|c|c|}
\hline \multicolumn{3}{|c|}{ الانتباه } & \multicolumn{3}{|c|}{ التخطيط } \\
\hline الارتباطد & عدد الفقرات & الاختبارات & الارتباط معامل & عدد & الاختبارات \\
\hline,$+ \mathrm{VV}$ & $r$ & ئبات المدرك & $\cdot, \wedge \varepsilon$ & $\varepsilon$ & مضاهات الأعداد \\
\hline,$+ \gamma_{7}$ & $\varepsilon$ & البحث من الأعداد & $\cdot, \sqrt{ } \cdot 9$ & r & الترميز المخطط \\
\hline,$+ \wedge)$ & 7 & تغير المدرك & $\cdot$-,人 & ᄉ & التوصيل المخطط \\
\hline \multicolumn{3}{|c|}{ التتابع } & \multicolumn{3}{|c|}{ الآتاني } \\
\hline الارتباط معامل & عدد الفقرات & الاختبارات & الارتباط معامل & عدد & الاختبارات \\
\hline,$+ \mathrm{VA}$ & rY & سلسل الكلمات & $\cdot, \wedge$. & سץ & المصفوفات غير اللفظية \\
\hline,$+ \mathrm{YV}$ & $r$ r. & إعادة الجمل & $\cdot, \vee_{7}$ & rV & العلاقات المكانية اللفظية \\
\hline,$+ \wedge)$ & YI & أسئلة الجمل & $\cdot, \wedge 0$ & $\varepsilon V$ & ذاكرة الأثكال \\
\hline
\end{tabular}

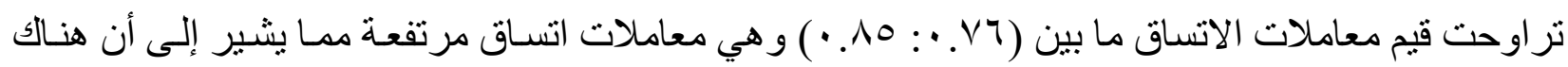

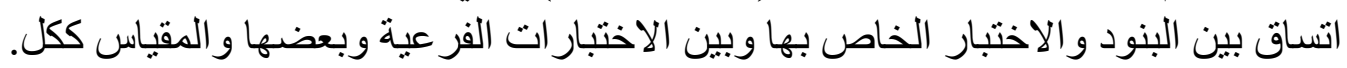
ثبات منظومة التقييم المعرفي

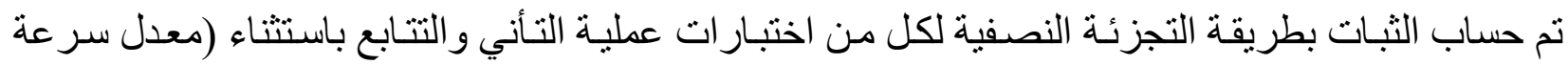

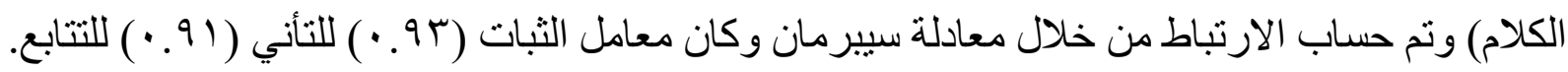
ثبات المنظومة في البيئة العربية

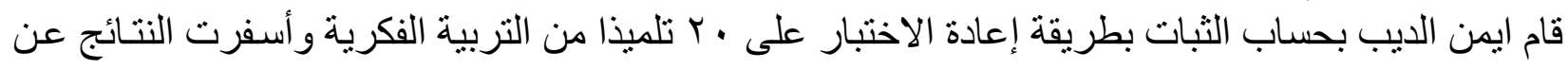

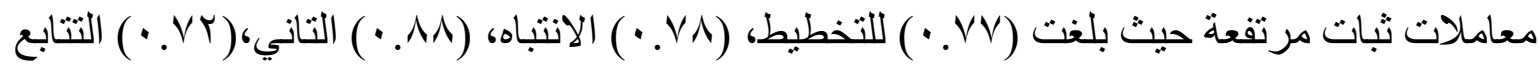




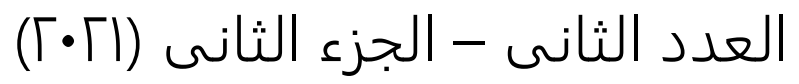
مجلة بحوث
"العلوم التربوية"

\section{ثبات المقياس في البحث الحالي}

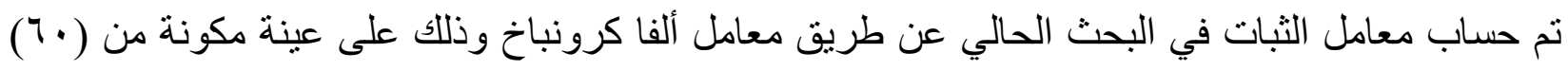

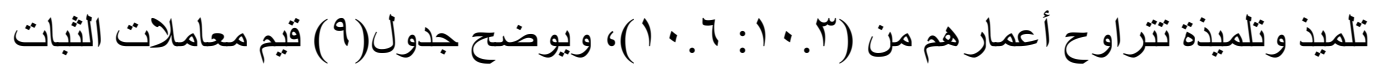

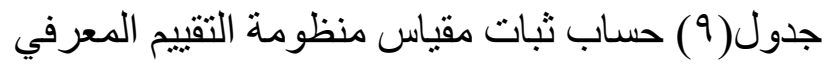

\begin{tabular}{|c|c|c|c|c|c|}
\hline \multicolumn{3}{|c|}{ الانتباه } & \multicolumn{3}{|c|}{ التخطيط } \\
\hline الفاكروتباخ & مدثد & الاختبارات & الفاكرونباخ & الفقرات & الاختبارات \\
\hline$\cdot, \wedge 7$ & $r$ & ئبات المدرك & $*, v_{*}$ & $\varepsilon$ & مضاهات الأقداد \\
\hline$\cdot, \vee \wedge$ & $\varepsilon$ & الأحث من اد & ד & r & الترميز المخطط \\
\hline • & 7 & تغير المدرك &,+ 10 & 人 & التوصيل المخطط \\
\hline \multicolumn{3}{|c|}{ التتابع } & \multicolumn{3}{|c|}{ التياني } \\
\hline الفاكروتباخ & الفقرات & الاختبارات & الفاكرونباخ معامل & الفقرات & الاختبارات \\
\hline$\cdot, \vee \varepsilon$ & $r v$ & سلسب الكلمات &,$+ \wedge+$ & س & المصفوفات ثير اللفظية \\
\hline$\cdot, \vee \wedge$ & $r \cdot$ & إعادة الجمل & •,人ז & $r r$ & العلاقات المكانية اللفظية \\
\hline$\cdot, \wedge 1$ & $r$ & أسئلة الجمل &,$+ v_{0}$ & $\varepsilon \gamma$ & ذاكرة الأثيكال \\
\hline
\end{tabular}

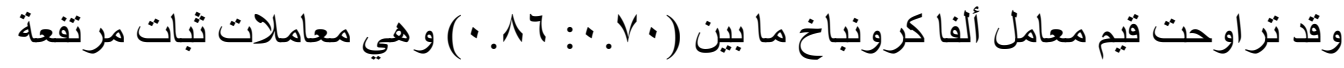

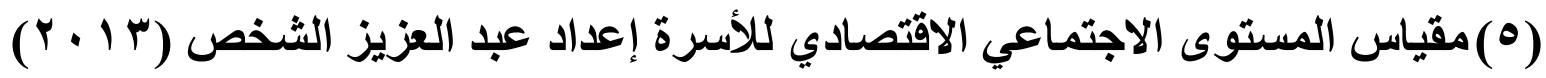

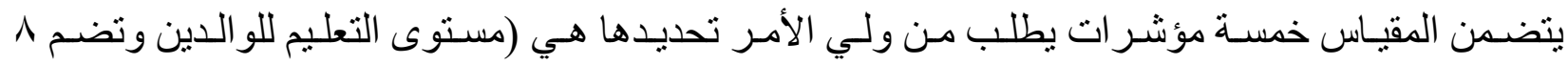

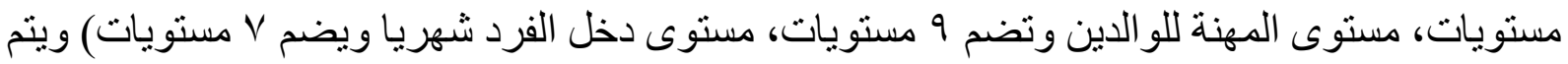
تقدير المستوى الاجتماعي الاقتصادي للأسرة عن طريق استخدام المعادلة التنبؤية التالية: ص= صr

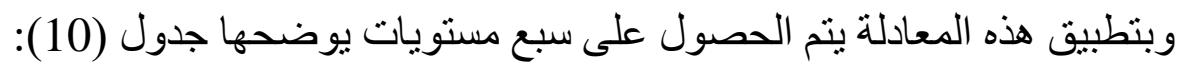

جدول(10) تصنيف مستويات المستوي الاجتماعي الاقتصادي 


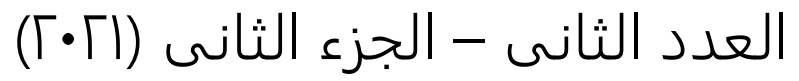
مجلة بحوث
"العلوم التربوية"

\begin{tabular}{|c|c|c|}
\hline \multirow{6}{*}{ السيكومثرياً } & معامل الارتباط & التبند \\
\hline & $\cdot, \mathrm{VV}$ & الجند الأول \\
\hline & $\cdot, \lambda 7$ & اللبند الثناني \\
\hline & • & البند الثالث \\
\hline & $\cdot, \tau \varepsilon$ & البتد الترابع \\
\hline & $\cdot, \wedge 9$ & البند الخامم \\
\hline
\end{tabular}

الخصائص للمقياس صدق مقياس المستوي الاجتماعي الاقتصادي

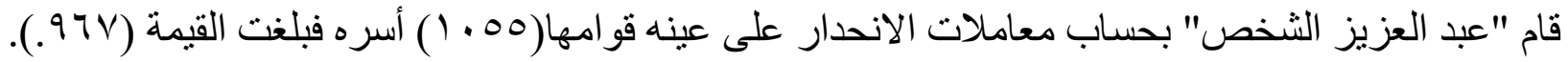

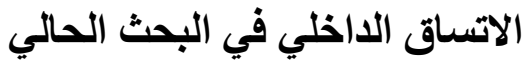

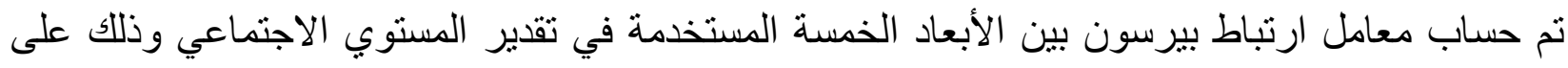

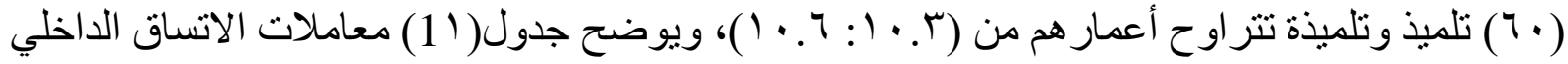

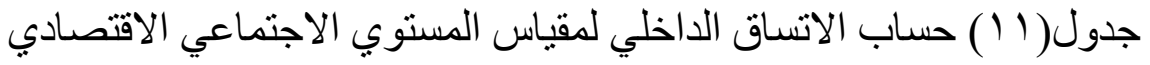

\begin{tabular}{|c|c|c|c|}
\hline الدرجة & المنتوي الاجتماعي الاقتصادي & الدرجة & الممتوي الاجتماعي الاتتصادي \\
\hline $171: 1 \leq 0$ & فوق المتوسط & $V Y: \varepsilon \wedge$ & منخفض جذا \\
\hline $195: 179$ & مرتقع & $9_{7}: \mathrm{VT}$ & منخفض \\
\hline r) & مرتفع جدا & $1 r \cdot: 9 \gamma$ & دون المتوسط \\
\hline & & $|\varepsilon \varepsilon:| r \mid$ & متوسط \\
\hline
\end{tabular}

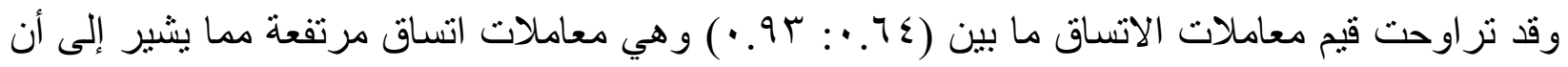

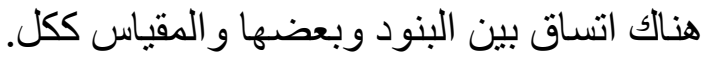

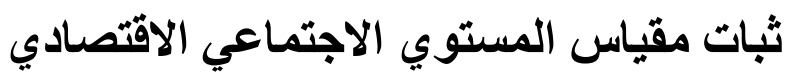

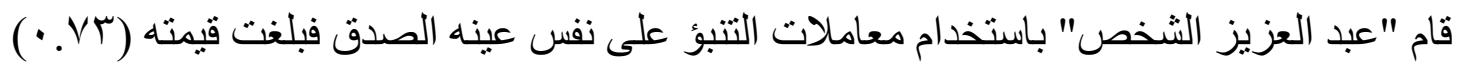
ثبات المقياس في البحث الحالي

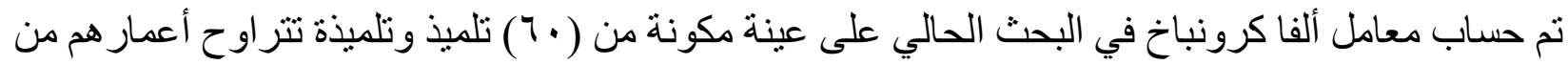

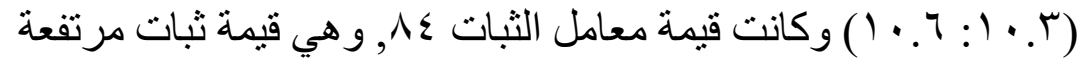

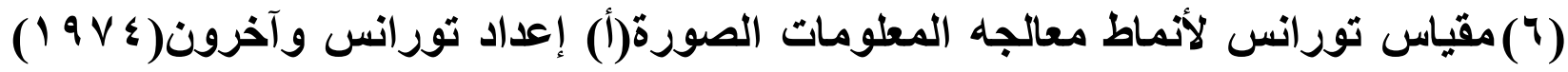
ترجمة أنور رياض، احمد عبادة (7 ( 9 ( ) ) 


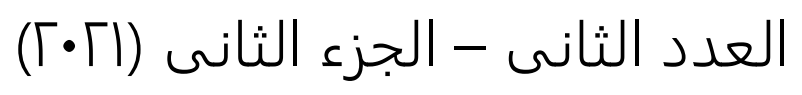

مجلة بحوث

"العلوم التربوية"

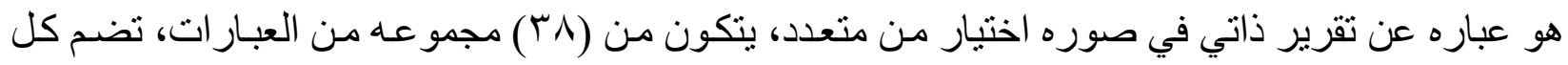

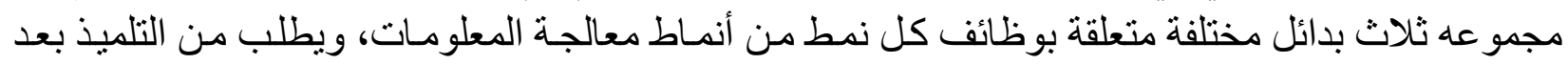

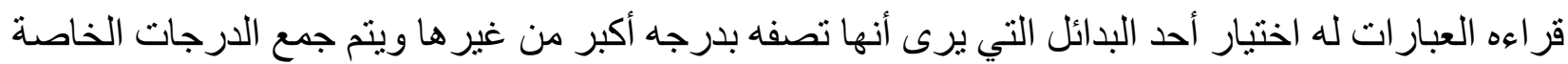
بكل نمطويعد النمط المسيطر هو النمط الذي يحصل فيه التلميذ علي درجة الكبر الكبر من الأنماط الأخرى.

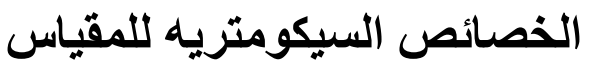
صدق مقياس أنماط معالجة المعلومات لإنيات

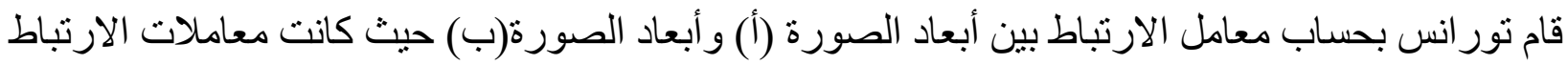

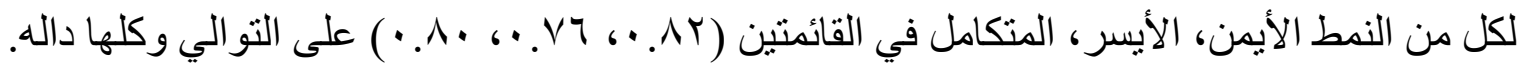

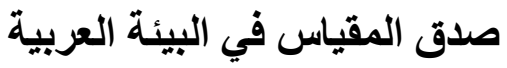

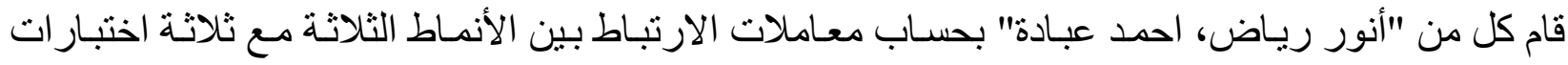

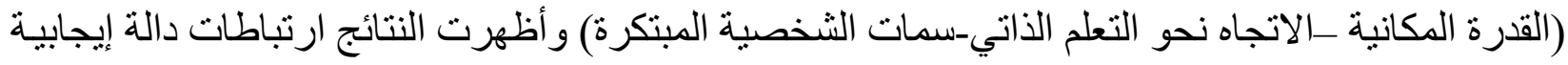

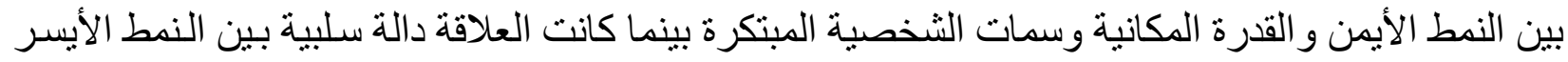

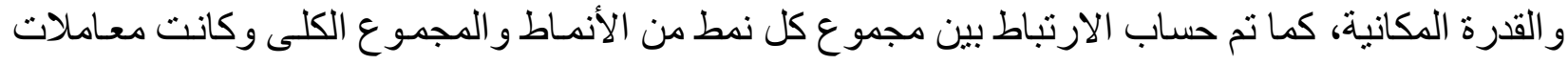

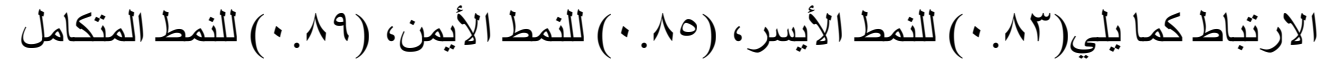

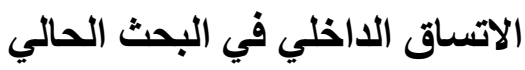

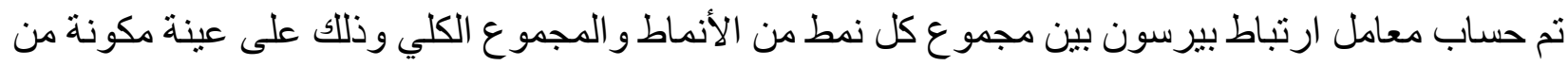

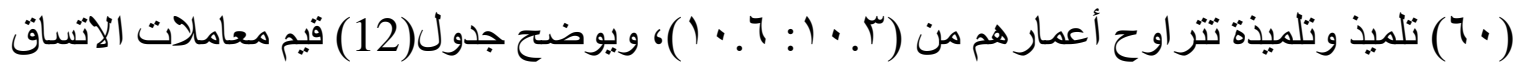
جدول(12) حساب الاتساق الاخلي لمقياس أنماط معالجة المعلومات

\begin{tabular}{|c|c|c|c|}
\hline |آنمط المتكامل & النمط الأيسر & النمط الأيمن & النمط \\
\hline , $\lambda V$ & , 49 & , & معامل الارتباط \\
\hline
\end{tabular}

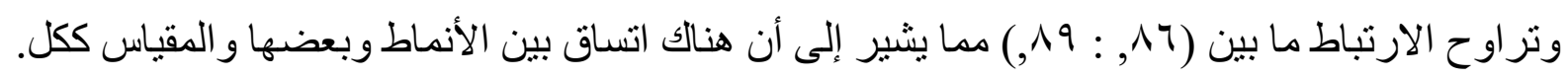

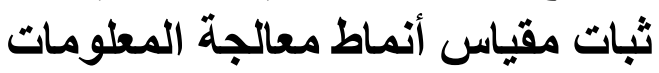

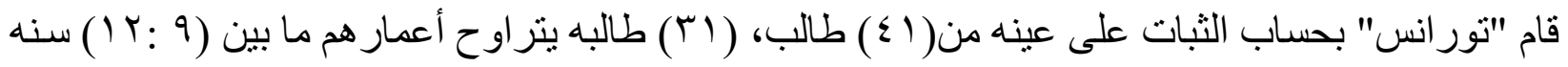

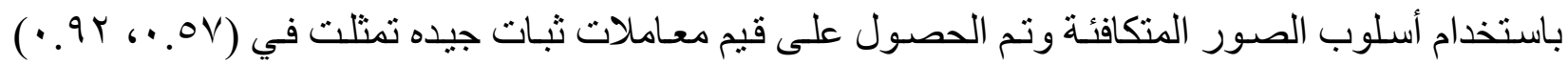

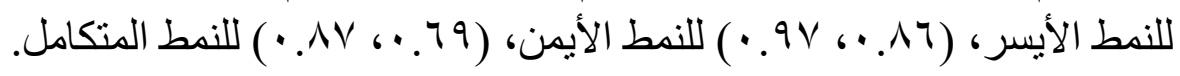

ثبات المقياس في البيئة العربية 


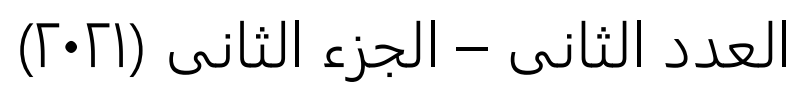

\section{مجلة بحوث \\ "العلوم التربوية"}

قام "أنور رياض و احمد عبادة" بحسـاب ثبات المقياس عن طريق إعادة التطبيق بفاصل زمني أسبو عين

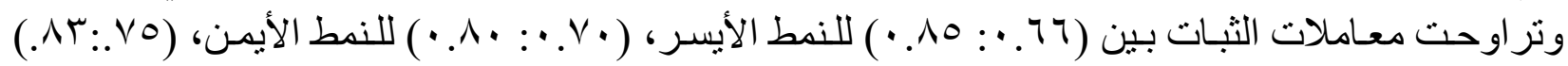

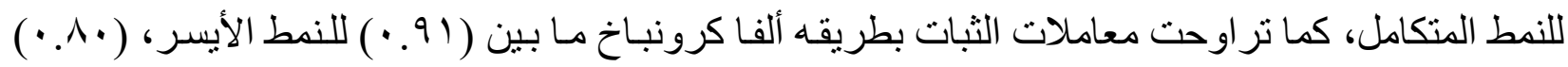

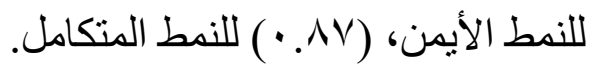

ثبات المقياس في البحث الحالي

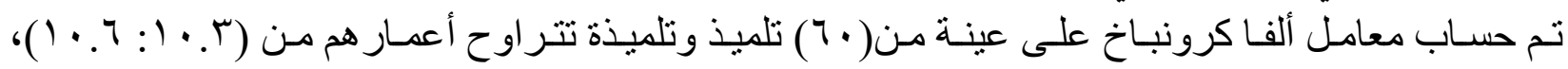
ويوضح جدول(13) قيم معاملات الثبات جدول(13) حساب ثبات مقياس أنماط معالجة المعلومات

\begin{tabular}{|c|c|c|c|}
\hline النمط المنكامل & النمط الأيسر & النمط الأيمن & النمط \\
\hline , $\mathrm{V}$ & ,人 $\varepsilon$ & سג, & تعامل الفاكرونباخ \\
\hline 个人 & ↔人 & 个人 & عدد البنو2 \\
\hline
\end{tabular}

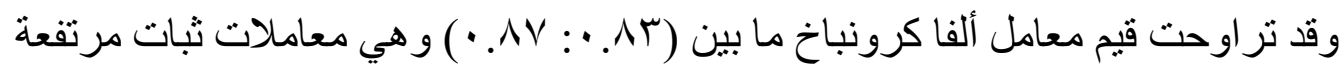
ثانيا: أدوات القياس

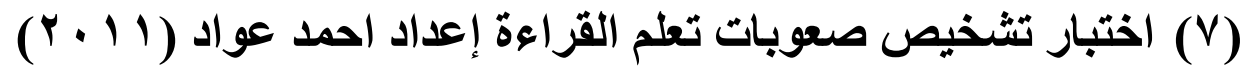

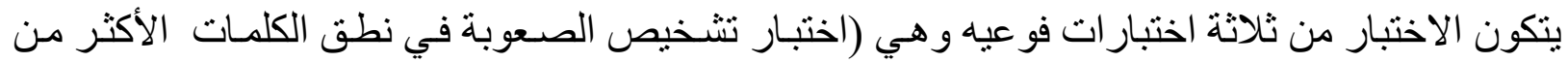

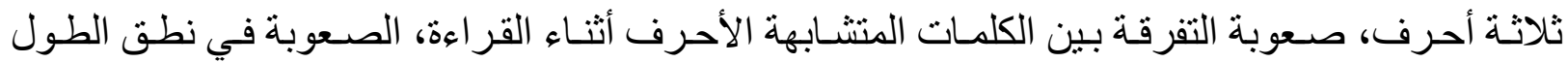

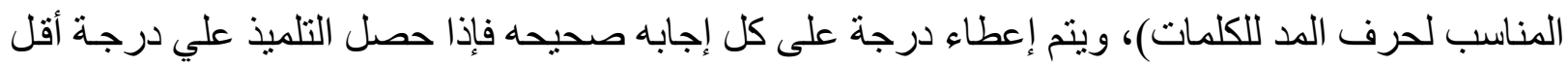

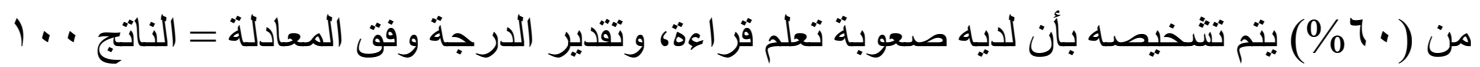
الخصائص السيكومترية للاختبار

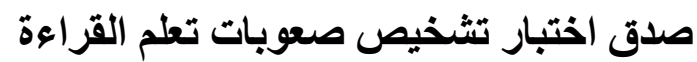

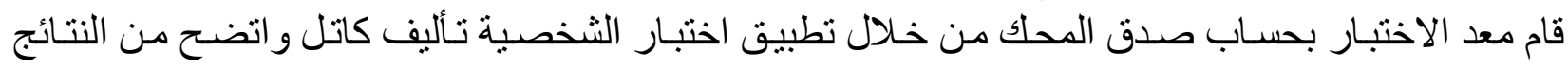
وجود فروق ذات دلاله إحصـائية عند مستوى ( . . · ) بين التلاميذ العاديين والتلاميذ المنخفضين

تحصيلياً

الاتساق الداخلي في البحث الحالي

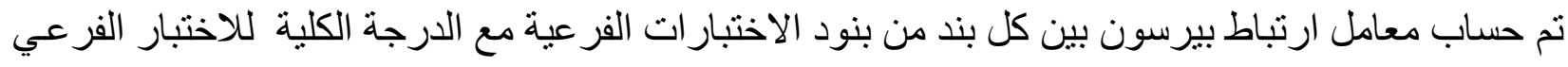

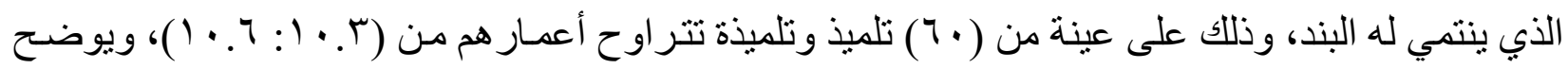
جدول(14) قيم معاملات الاتساق الداخلي

جدول(14) حساب الاتساق الداخلي لاختبار تشخيص صعوبات تعلم القراءة 


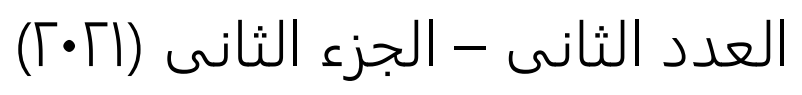
مجلة بحوث

"العلوم التربوية" بحوبة"

\begin{tabular}{|c|c|c|c|c|c|}
\hline \multicolumn{2}{|c|}{ الاختبار الفرعي الثالث } & \multicolumn{2}{|c|}{ الاختبار الفزعي الثاني } & \multicolumn{2}{|c|}{ الاختبار الفرعي الأول } \\
\hline معامل الارتباط & البتذ & معامل الازتباط & الينذ & معامل الإنتباط & البند \\
\hline$\cdot$, 人ᄉ & זי & $\cdot, 91$ & $\mathrm{v}$ & $\cdot, \vee \vee q$ & , \\
\hline$\cdot, 91$ & $1 \varepsilon$ & ד & ᄉ & $\cdot, \wedge \varepsilon$ & r \\
\hline$\cdot, \cdot, 9 \varepsilon$ & 10 & $\cdot$, , & 9 & $\cdot, 9$. & $r$ \\
\hline שים • & 17 & $\cdot, \times 9$ & $1 \cdot$ & $\cdot$, 人 & $\varepsilon$ \\
\hline$\cdot, \wedge 9$ & $i v$ &,+ 9. & 11 & - & $\circ$ \\
\hline$\cdot, V T$ & ) & ד ד, • & it & $*, \vee \wedge$ & 7 \\
\hline
\end{tabular}

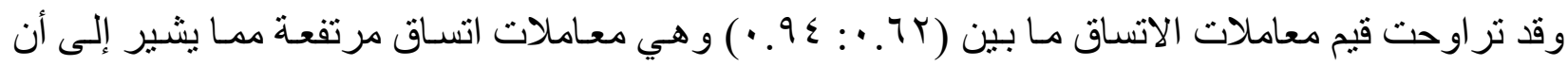

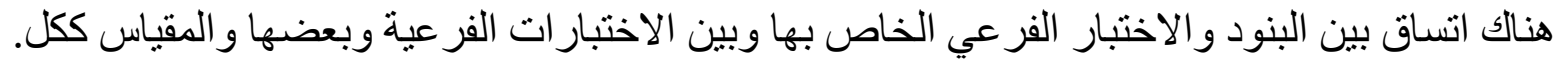

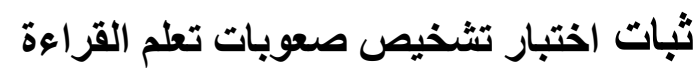

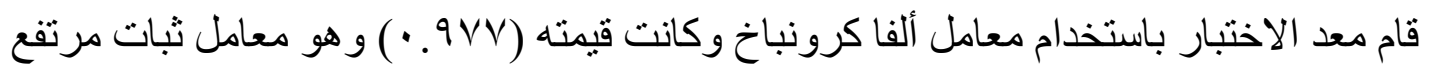

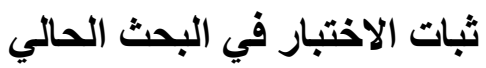

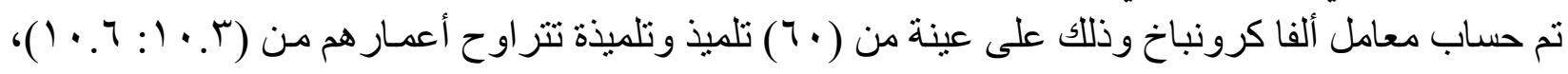
ويوضح جدول(15) قيم معاملات الثبات جدول(15) حساب ثبات اختبار تشخيص صعوبات تعلم القر اءة

\begin{tabular}{|c|c|c|}
\hline معامل الفاكروتباخ & عدد النيود & الاختبار \\
\hline$\cdot, \wedge 7$ & 7 & الاختبار الفرقي الأول \\
\hline$\cdot, 9$. & 7 & الاختبار الفرعي الثاني \\
\hline$\cdot, \vee 9$ & 7 & الاختبار الفرعي الثالث \\
\hline . & ) & الدرجة الكلية \\
\hline
\end{tabular}

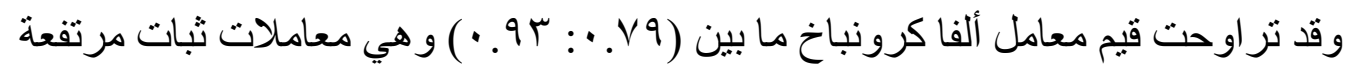

ثالثاً: أدوات المعالجة تراتة

(^) البرنامج العلاجي لصعوبات تعلم القراعة التلاميذ المرحلة الابتدائية ذوي النمط الأيمن في

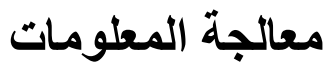

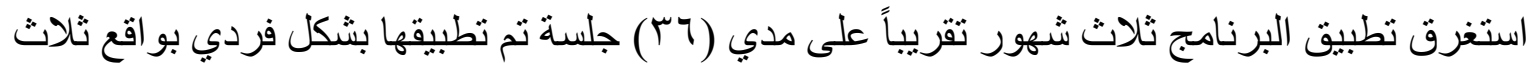

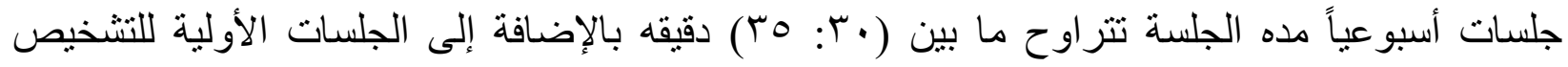
وتطبيق الأدوات، ويوضح جدول(4 (1) خطة سير جلسات البرنامج العلاجي 


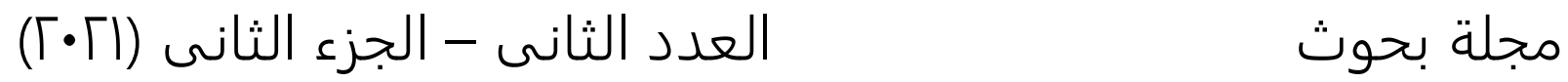

$$
\begin{aligned}
& \text { "العلوم التربوية" }
\end{aligned}
$$

جدول(7 (1) خطة سير جلسات البرنامج العلاجي

\begin{tabular}{|c|c|c|c|c|}
\hline \multicolumn{5}{|c|}{ النمط الأيمن في معالجة المعلومات } \\
\hline الأدوات & الأساليب العلاجية & الفنيات العلاجية & أهداف الجلسة & الجلسة الجس \\
\hline & & المناقئة والحوار & جلسة تمهيدية & الجلسة(1) \\
\hline منــل موست إيقاف - & - الاستزخاء - المنفس المخي & التمخجة -التية التعزيز & 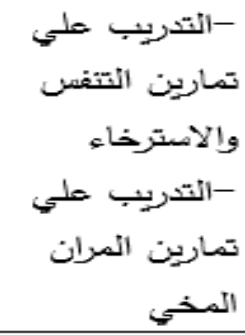 & الجلهة (r: ع ) \\
\hline 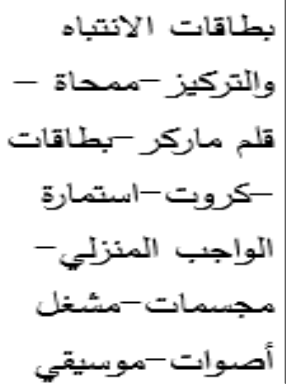 & - & التماجبة التئية التعزيز & 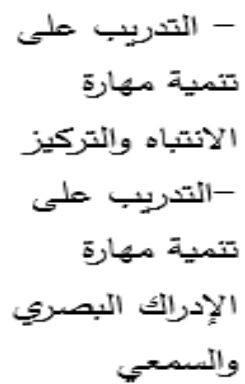 & الجلسة (0 : ד (1) \\
\hline بطاقات الذاكرة- & - الاسمتزخاء - التنفس - المرات المخي & 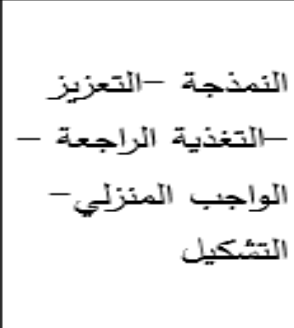 & 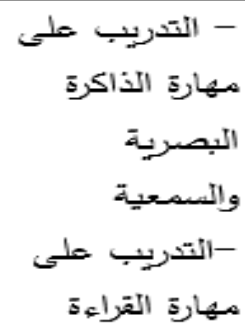 & الجلسة (V) : (r) \\
\hline & & المناقئة والحوار & - - القيام البعديق أدوات & الجلسة (ד: ه:م) \\
\hline
\end{tabular}

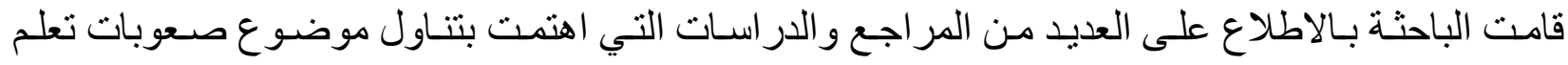

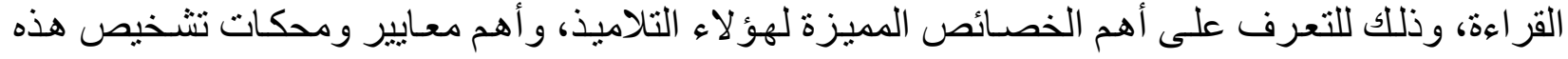

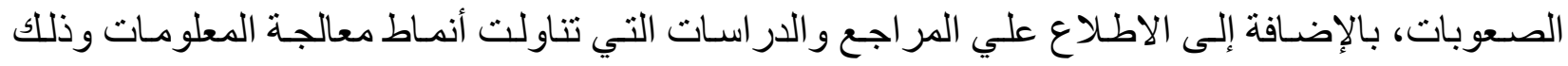

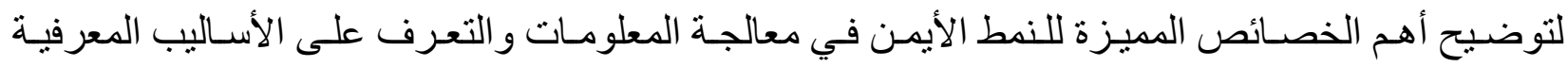

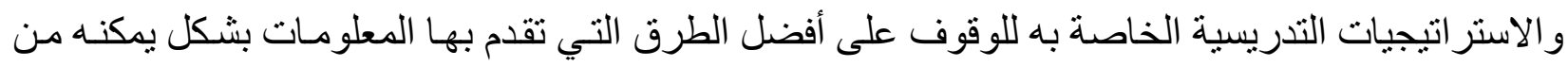




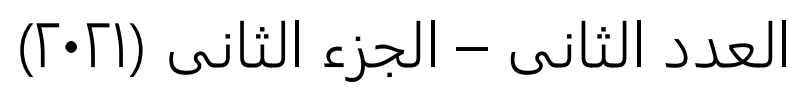

\section{مجلة بحوث \\ "العلوم التربوية"}

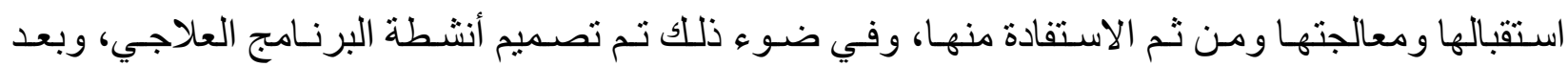

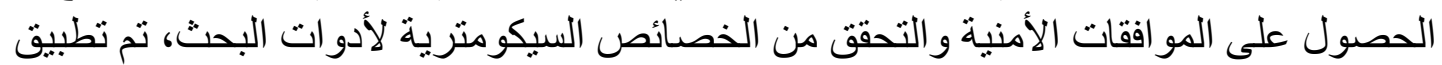

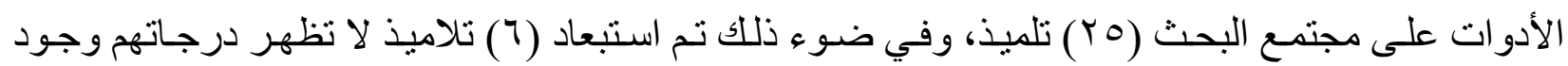

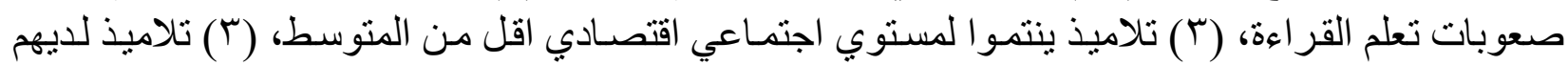

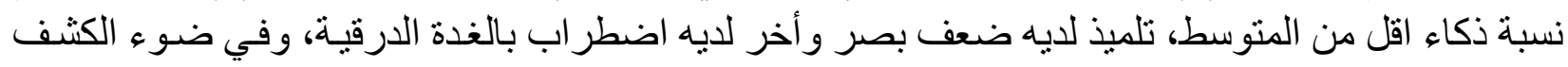

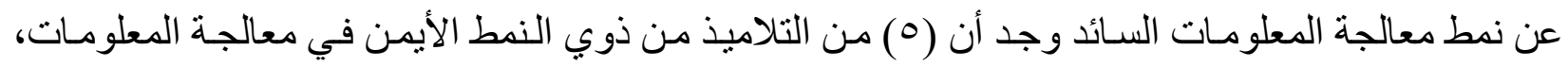

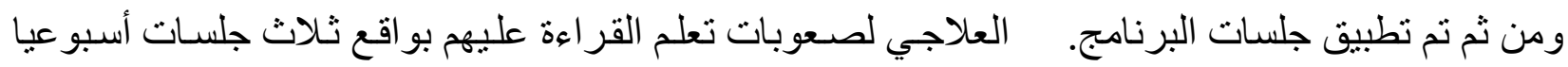

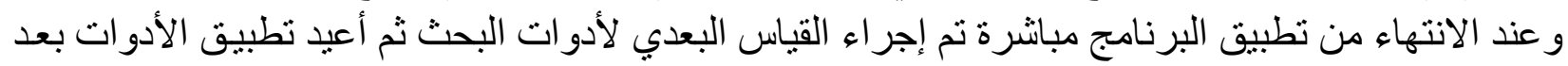
ما يقرب من شهرين من تطبيق البرنامج (القياس التتبعي)

\section{نتائج البحث ومناقشاتها}

نتائج الفرض الأول: الذي ينص على (يوجد فروق بين القياسين القبلي و البعدي في صعوبات تعلم القراءة

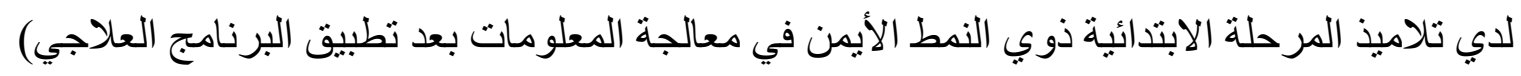

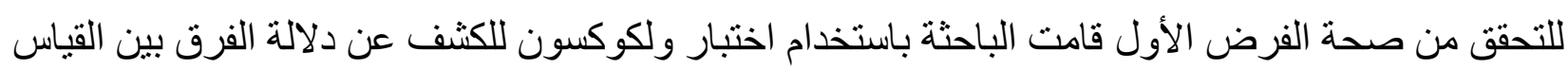

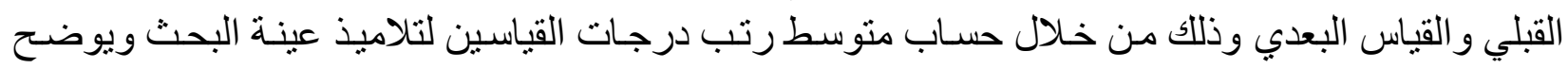

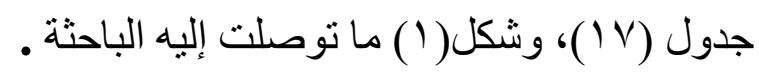




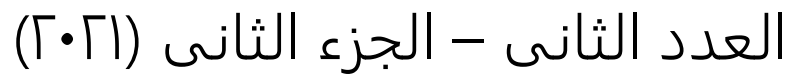
مجلة بحوث
"العلوم التربوية"

جدول(V ا ) دلالة الفروق بين أداء التلاميذ في القياسين البعدي -التتبعي على اختبار صعوبات القراءة

\begin{tabular}{|c|c|c|c|c|c|c|c|}
\hline مستوي & قيمة & مجموع الزرتب & متوبسط & المتوبسطي & العدد & قبلي -بعدي & \\
\hline \multirow{4}{*}{ | دال } & \multirow{4}{*}{$r, \cdot r$} & - & $*$ & r & . & الززتب السسالبة & \multirow{4}{*}{ 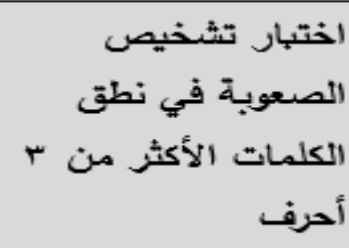 } \\
\hline & & 10 & r & $0 \cdot, 11$ & 0 & الزتب الموجبة & \\
\hline & & - & * & & . & الزيتب المتعادلة & \\
\hline & & & & & 0 & الإجمالثي & \\
\hline \multirow{4}{*}{ 2 } & \multirow{4}{*}{$r, \cdot r$} & - & $*$ & YY, T & . & الزتبب السالبة & \multirow{4}{*}{ 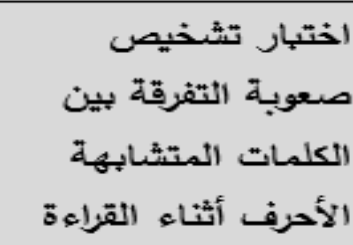 } \\
\hline & & 10 & r & $0 \cdot, r$ & 0 & الزتب الموجبة & \\
\hline & & . & + & & . & الزبتب المتعادلة & \\
\hline & & & & & 0 & الإجمالخي & \\
\hline \multirow{4}{*}{ | دال } & \multirow{4}{*}{$r, \cdot r$} & . & + & 19,1 & . & الزبتب السالبة & \multirow{4}{*}{ 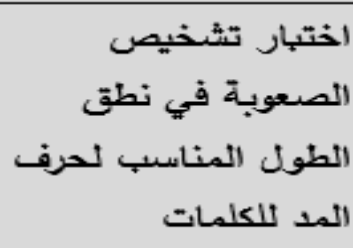 } \\
\hline & & 10 & r & $\varepsilon V$ & 0 & الزيب الموجبة & \\
\hline & & * & * & & . & الزتب المتعادلة & \\
\hline & & & & & 0 & الإجمالثي & \\
\hline \multirow{4}{*}{ دال } & \multirow{4}{*}{$Y, \cdot r$} & * & + & $\varepsilon 7,7$ & . & الزبتب السالبة & \multirow{4}{*}{ اختبار تثخية الكلية على } \\
\hline & & 10 & 0,7 & $1 \leqslant \lambda, 0$ & $\circ$ & الزتب الموجبة & \\
\hline & & - & $*$ & & . & الزبتب المتعادلة & \\
\hline & & & & & $\circ$ & الإجمالّي & \\
\hline
\end{tabular}

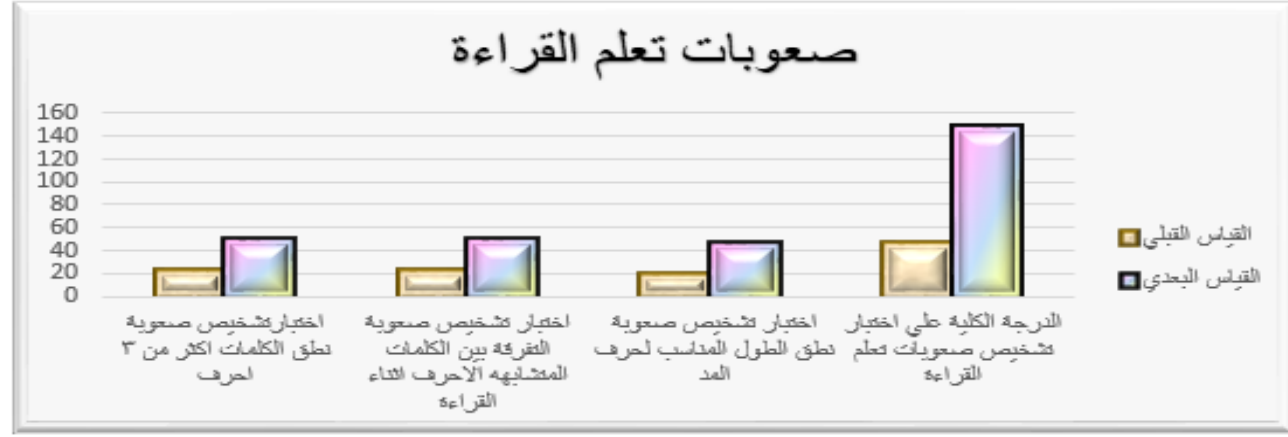

شكل ( ) المتوسطات الحسابية لأبعاد اختبار صعوبات تعلم القراءة في القياسين (القبلي_البعدي) وفي ضوء النتائج السابق يتضح أن: قيمة Z المحسوبة للارجة الكلية على اختبار صعوبات تعلم القر اءة ومـا

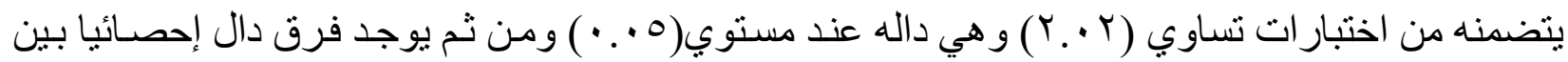

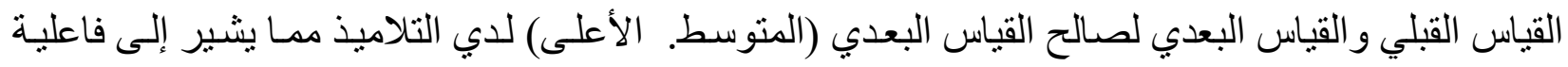




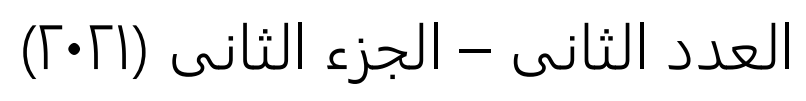
مجلة بحوث

"العلوم التربوية" بحوثة"

البرنامج العلاجي في التخفيف من صعوبات تعلم القراءة لدي تلاميذ المرحلة الابتدائية ذوي النمط الأيمن في

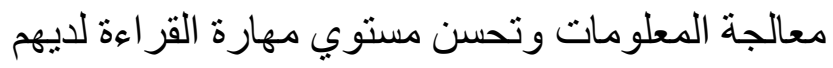

وربما يرجع السبب في هذا التحسن إلي: -

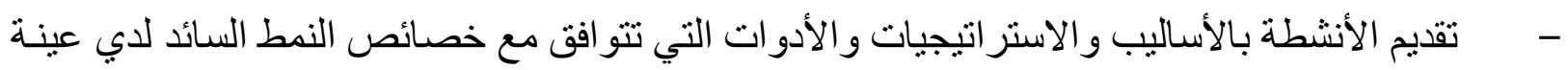

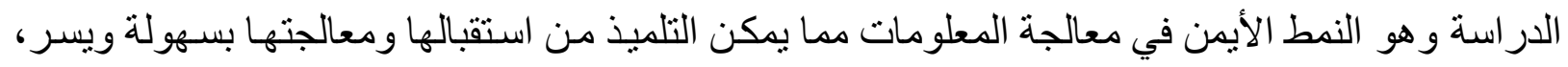

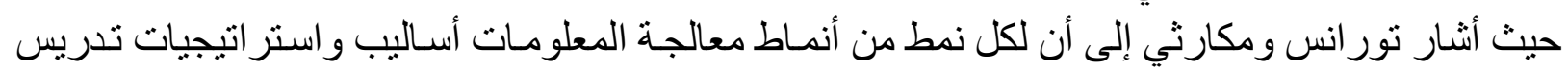

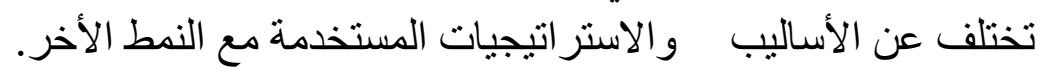

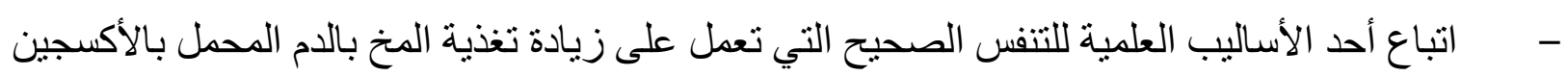

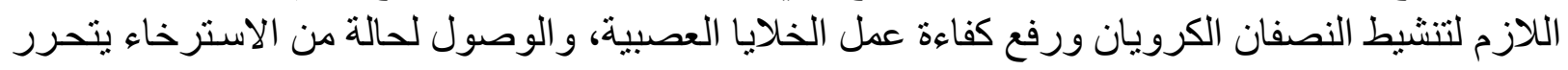

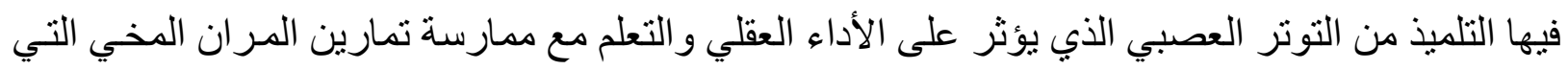

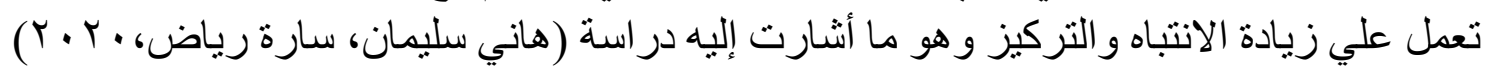

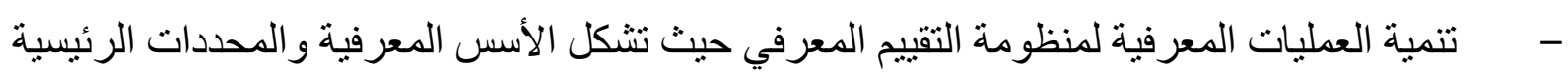

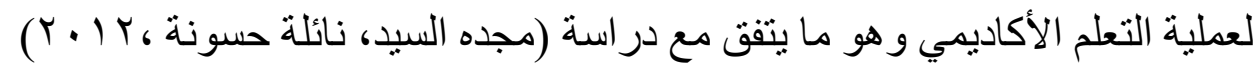

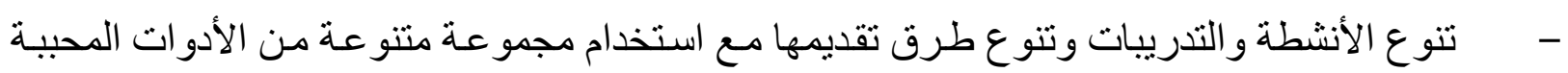

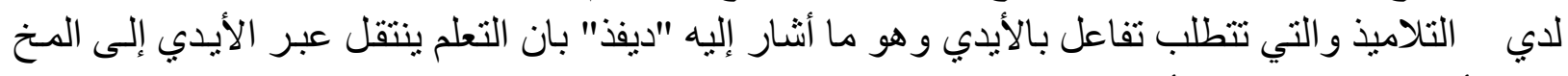

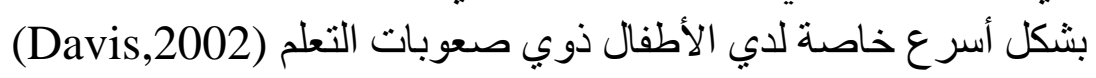

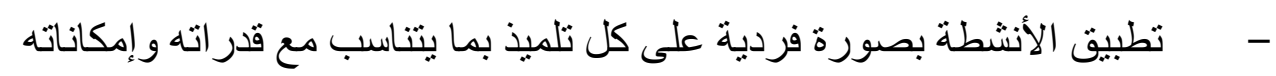

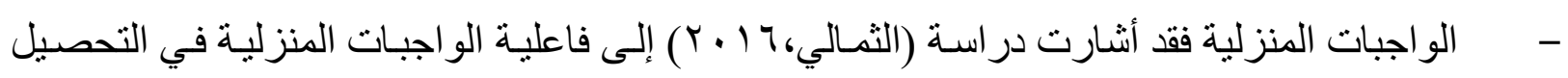

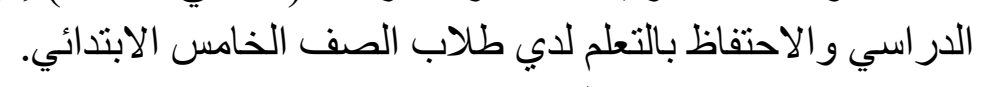

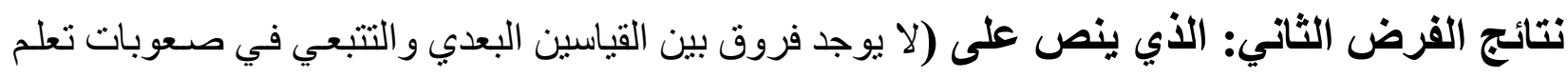

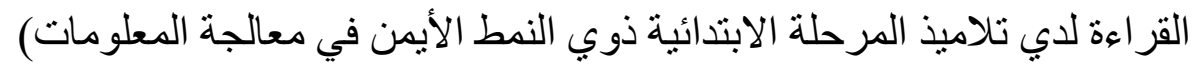

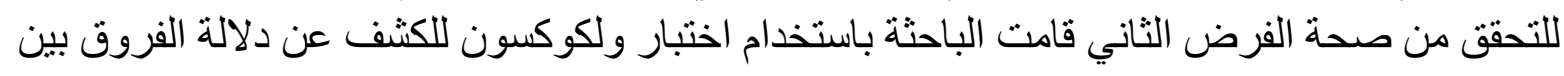

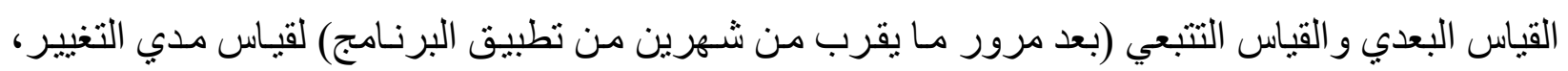

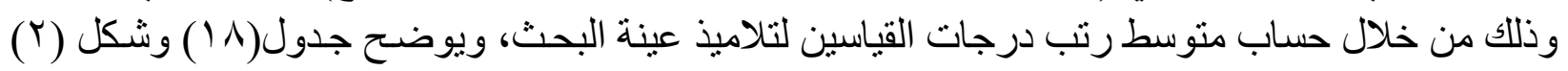

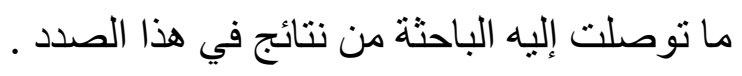




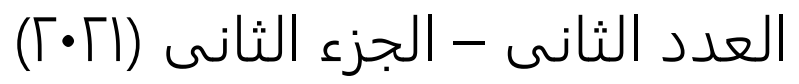
مجلة بحوث
"العلوم التربوية"

جدول(^ ( ) دلالة الفروق بين أداء التلاميذ في القياسين البعدي ـالتتبعي على اختبار صعوبات القر اءة

\begin{tabular}{|c|c|c|c|c|c|c|c|}
\hline الدلانة & المحسبوبة & مجمتوع & متوبسط & المتوبسي & التعدد & بعدي -تتبحي & \\
\hline \multirow{4}{*}{ شير } & \multirow{4}{*}{$\cdot, \varepsilon \vee$} & , & , & $01, \varepsilon$ & , & الزيتب النسالبة & \multirow{4}{*}{ 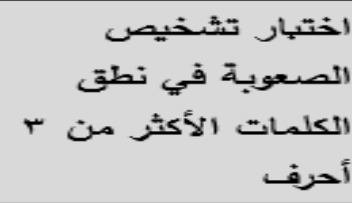 } \\
\hline & & 1 & r, r & Or, r & $r$ & الززتب الموجبة & \\
\hline & & & & & , & الزيتب المتعادنة & \\
\hline & & & & & 0 & الإجمالي & \\
\hline \multirow{4}{*}{ هَ" همّر } & \multirow{4}{*}{ Chart Title } & $r$ & $r$ & $0 \cdot, r$ & , & الزتب السسالبة & \multirow{4}{*}{ 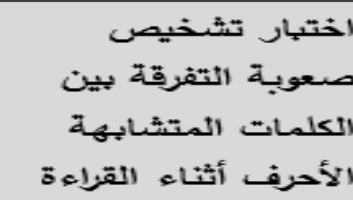 } \\
\hline & & 人 & $r, T$ & $0 \cdot, \lambda$ & $r$ & الزرتب الموجبة & \\
\hline & & & & & , & الثزتب المتعادنة & \\
\hline & & & & & 0 & الإجمانلي & \\
\hline \multirow{4}{*}{ عير } & \multirow{4}{*}{ דיז, } & $r, 0$ & $r, 0$ & $0+, 7$ & ? & الكزتب السسالبة & \multirow{4}{*}{ 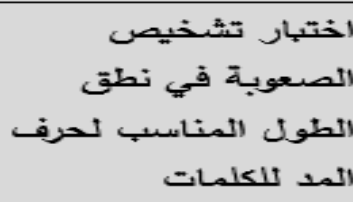 } \\
\hline & & $1, T, 0$ & r, r, & $0,1, \varepsilon$ & $\varepsilon$ & الكزتب الموجبة & \\
\hline & & & & & $\cdot$ & الثزتب المتعادنة & \\
\hline & & & & & 0 & الإجمالثي & \\
\hline \multirow{4}{*}{ شير } & \multirow{4}{*}{$*, \varepsilon$} & $r$ & $r$ & I $\leqslant \lambda, r$ & , & الزيتب السسالبة & \multirow{4}{*}{ اختبار تثخية الكلية على تعلى الثلمراءة } \\
\hline & & $\varepsilon$ & $r$ & 1 纟八,人 & $r$ & الزرتب الموجبة & \\
\hline & & & & & $r$ & الثزتب المتعادلة & \\
\hline & & & & & 0 & الإجمالمي & \\
\hline
\end{tabular}

\section{صعوبات تعلم القراءة}

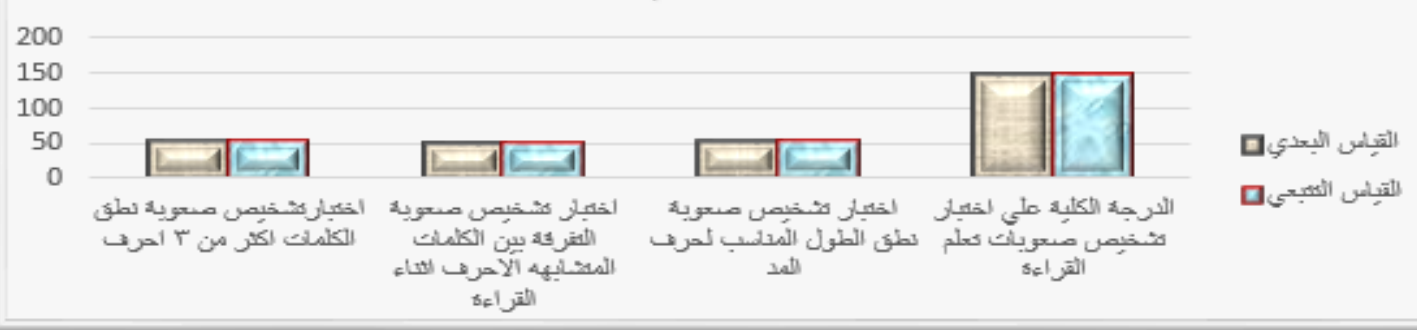

شكل (r) المتوسطات الحسابية لأبعاد اختبار صعوبات تعلم القر اعة في القياسين (البعدي_التتبعي)

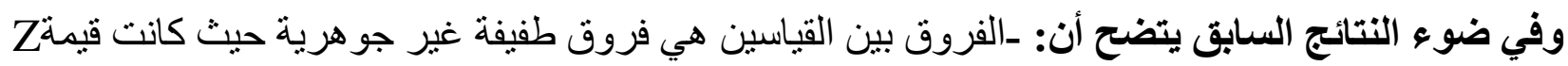

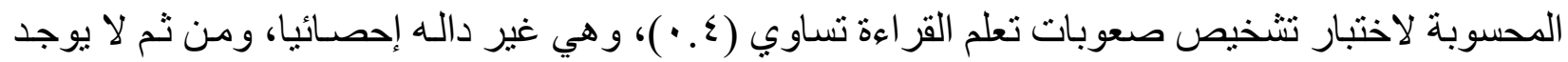

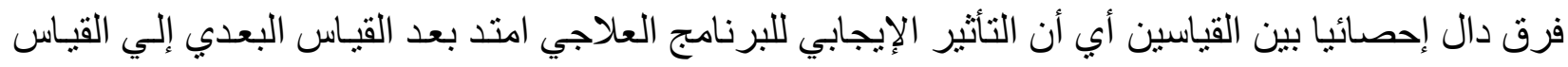

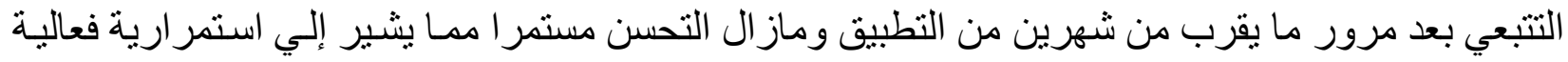




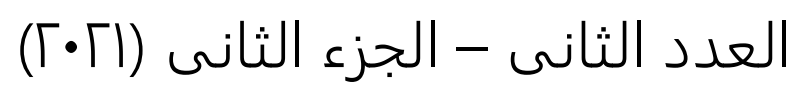

\section{مجلة بحوث \\ "العلوم التربوية"}

البرنامج العلاجي وفق نمط معالجة المعلومات السائد في التخفيف من صعوبات تعلم القراءة وتحسين مسنتوي

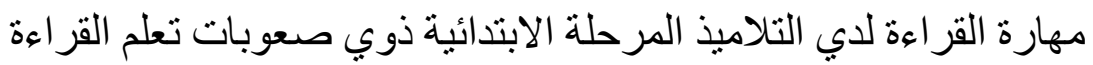

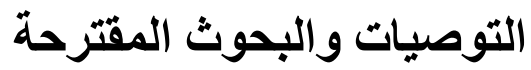

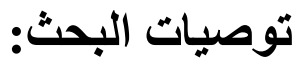

- يوصي بضرورة إعادة النظر في أساليب التدريس بحيث تر اعي أنماط معالجة المعلومات المختلفة - يوصي بتنوع الأنشطة والفنيات المستخدمة من قبل المعلم مما يساعد على تحقيق أقصى استفادة - يوصي بعقد دور ات تدرييية للمعلمين لتو عيتهم بخصائص ذوي صعو بات التعلم للمساعدة في الكثف المبكر البحوث المقترحة

- فعالية برنامج قائم على نمط معالجة المعلومات غير السائد في علاج صعوبات التعلم

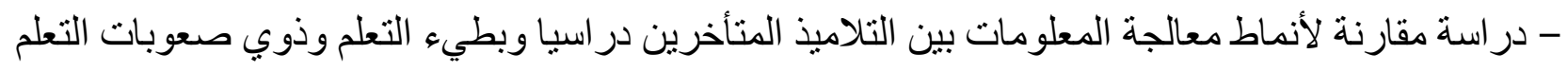
المراجع

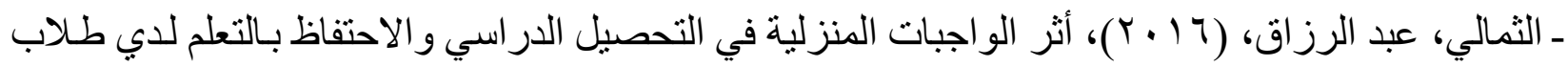

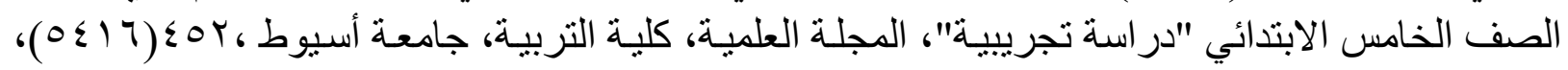

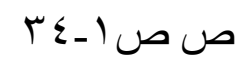

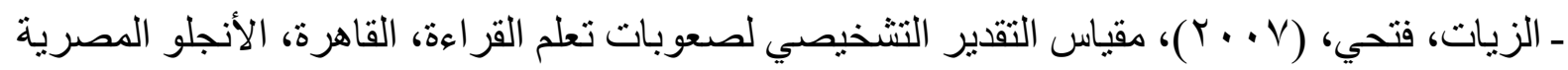

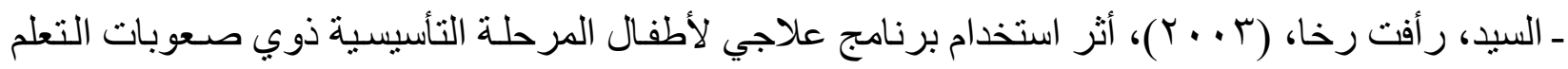

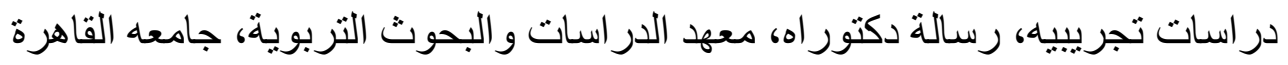

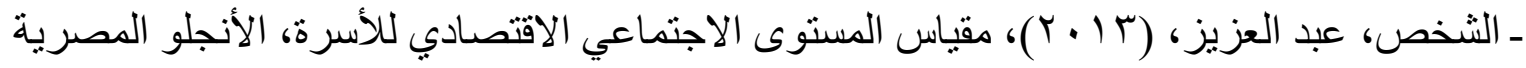

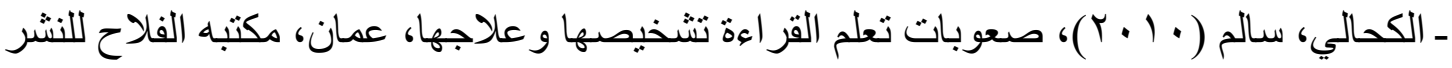

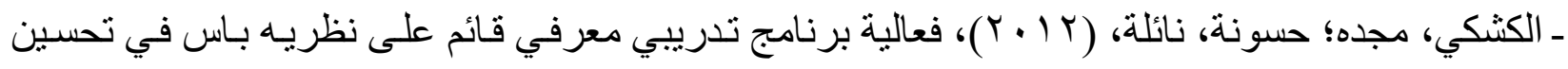

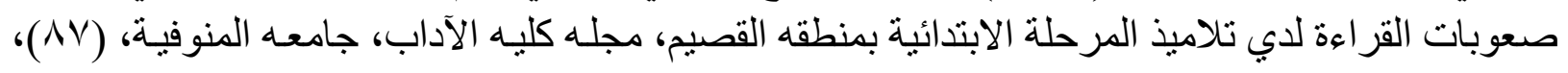

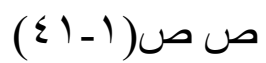

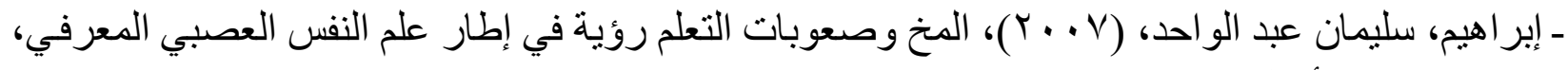

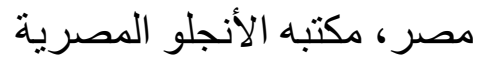

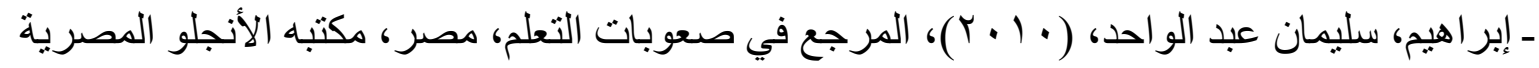

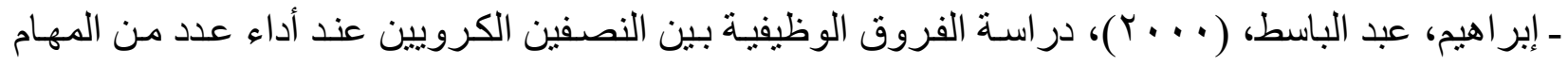

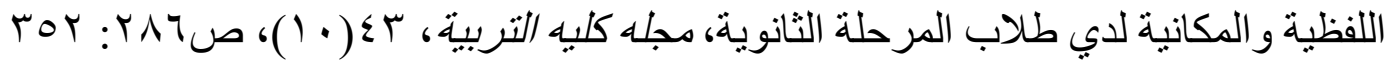

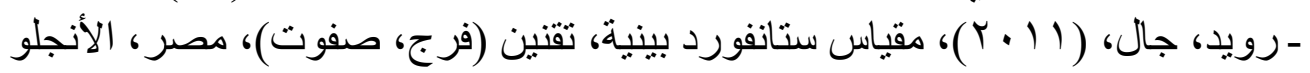

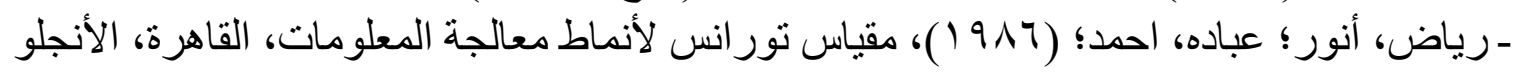




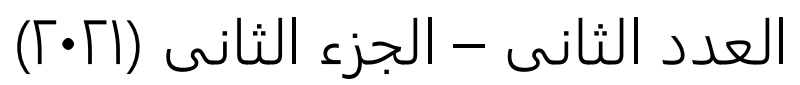

مجلة بحوث

"العلوم التربوية" مجولة "

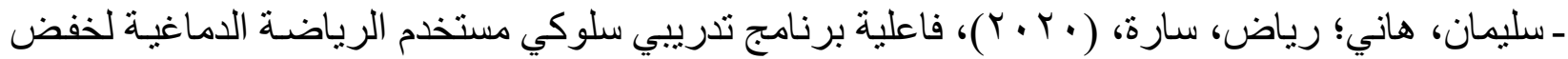

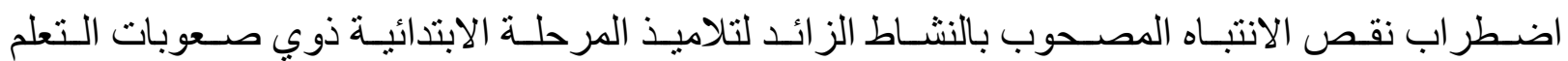

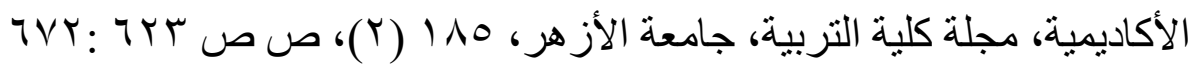

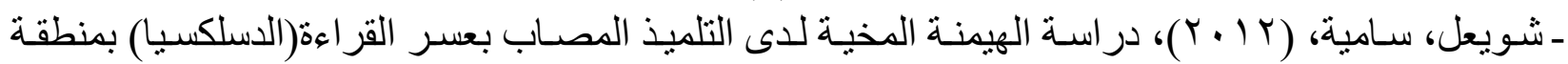

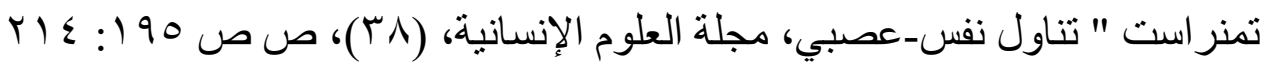

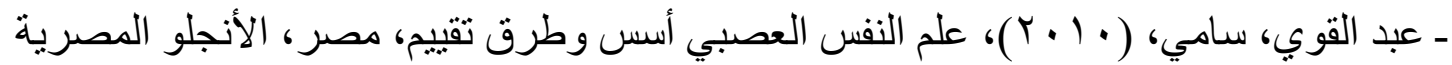

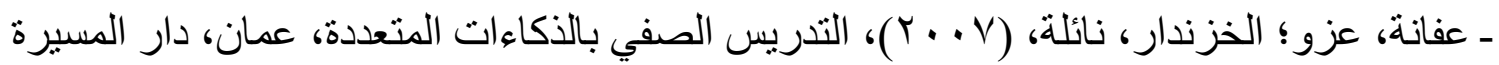

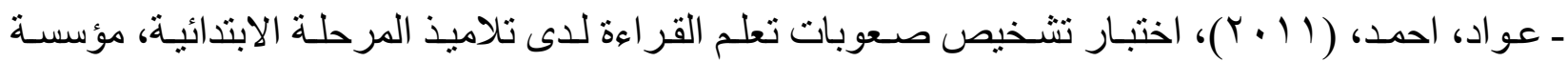

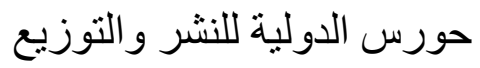

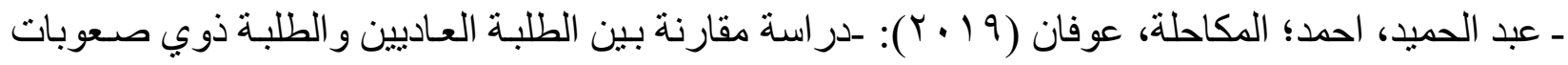

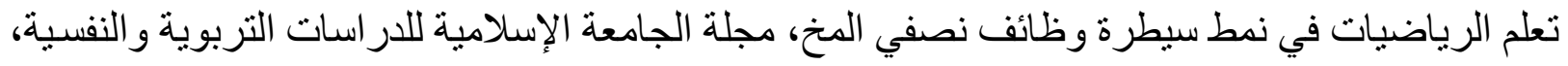

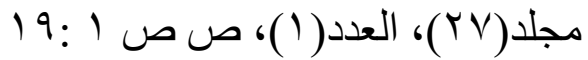

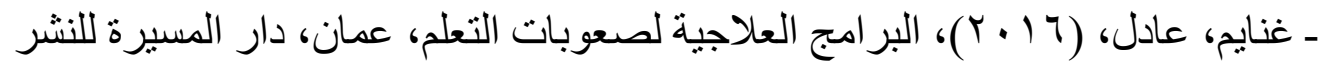

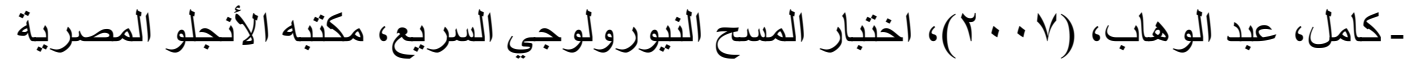

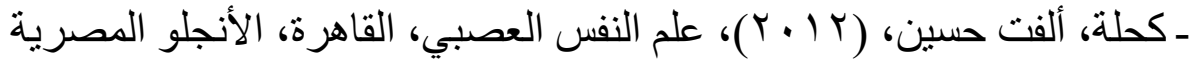

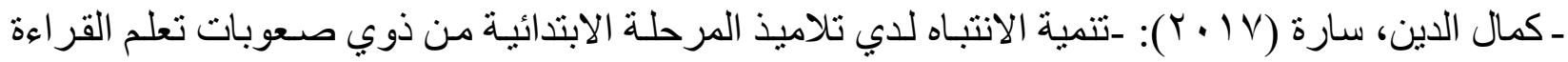

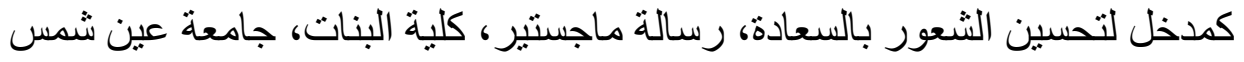

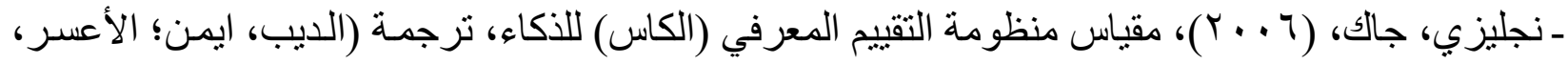
صفاء) القاهرة، مكتبة الأنجلو المصرية.

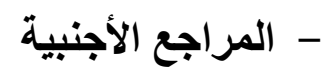

- Allington-Smith, P. (2006). Mental health of children with learning disabilities. Advances in Psychiatric Treatment, 12(2), 130-138.

- Davis, A(2002), Attention biases in attention deficit hyperactivity disorder, Abstracts international, $v(62), n(11), p$ 5368-b.

- Gebauer, D., Fink, A., Filippini, N., Johansen-Berg, H., Reishofer, G., Koschutnig, K. and Enzinger, C. (2012). Differences in integrity of white matter and changes with training in spelling impaired children: a diffusion tensor imaging study. Brain Structure and Function, 217(3), 747-760.

- Gilger, J. W., \& Kaplan, B. J. (2001). Atypical brain development: a conceptual framework for understanding developmental learning Disabilities, Developmental neuropsychology, 20(2), 465-481. 
- Marchman, K. M. (2001). A study of the nonverbal learning disabilities subtype and its impact on peer interaction and peer acceptance (Doctoral dissertation, Union Institute, Graduate College).

- McCarthy, R. A., \& Warrington, E. K. (1990). Cognitive neuropsychology: A clinical introduction.

- Obrzut, J. E., Boliek, C. A., Bryden, M. P., \& Nicholson, J. A. (1994). Age-and sex-related differences in left-and right-hemisphere processing by learning disabled children. Neuropsychology, 8(1), 75.

- Sandson, T. A., Bachna, K. J., \& Morin, M. D. (2000). Right hemisphere dysfunction in ADHD: Visual hemispatial inattention and clinical subtype. Journal of Learning Disabilities, 33(1), 83-90.

- Silagi, M. L., Radanovic, M., Conforto, A. B., Mendonça, L. I. Z., \& Mansur, L. L. (2018). Inference comprehension in text reading: Performance of individuals with right-versus left-hemisphere lesions and the influence of cognitive functions. PloS one, 13(5), 213-230..

- Spicer, S. M. (2012). Cognitive development of right hemisphere functioning from ages 4 to 8 (Doctoral dissertation, Fielding Graduate University).

- York, H. J. (1998). The effects of right/left hemispheric preference on academic achievement at the middle school level. dissertation, Abstract International, $V(58), n(8), p$ 140-15 

العدد الثانى - الجزء الثانى (IГ•Г)
مجلة بحوث
"العلوم التربوية"

\title{
The effectiveness of treatment program for reading disabilities for primary pupils with the right hemisphere to process information nan Samy Mohamed Hamed
}

Researcher - Educational Psychology-Faculty of women Ain-Shams University

Prof. Dr. Asmaa Abdel Moneim

Professor of Educational Psychology- Faculty of women Ain-Shams University

\section{Dr. Rania Maher wahdy}

Teacher of Educational Psychology- Faculty of women Ain-Shams University

\begin{abstract}
$\underline{\text { Abstract }}$
The aim of this research is to discover the effectiveness of the treatment program for reading disabilities for primary pupils with the right hemisphere to process information.The simple consists of (5) pupils suffering from reading disabilities with the right hemisphere to process information, the treatment program for reading disabilities was applied with methods and strategies that compatible with this hemisphere of the brain, this enable pupils with the right hemisphere to receive and process information easily.The program was applied in (3) sessions per week, the whole programs consists of (36) session, the time of each (30:35) minutes.The tools of the study were the Diagnostic Assessment Scale for Learning Difficulties to Read, the quick Neurological screening Test, the Diagnostic Test for Reading Difficulties, the Stanford-Binet Intelligence Scale, Fifth Edition, the Cognitive Assessment System Scale, the Family Socio-Economic Level Scale, and the Torrance Scale for Information Processing Patterns, (A) Edition, and the treatment Program.The result of this study indicated to the effectiveness of the treatment program for reading disabilities for primary pupils with the right hemisphere to process information.
\end{abstract}

keywords $\therefore$ Treatment program - Reading disabilities- The right hemisphere to process information 